\title{
A Tale of Two Pasts Ephemeral Reality and Monumental Memory
}

\author{
by Tzvetelina Videnova
}

A thesis submitted to the Faculty of Graduate and Postdoctoral Affairs in partial fulfillment

of the requirements for the degree of

Master of Architecture

Carleton University

Ottawa Ontario

(C2015 Tzvetelina Videnova 


\section{i Abstract}

What constitutes history? How exactly is the past remembered and is its recollection factual? Are physical memorials adequately reflecting History? Can we really speak of remembering when the commemorated materials evidently serve historically unrelated motives? Guided by these questions, this paper will argue for a de-monumentalizing approach towards the architecture of memorials. In a two-phased work, the thesis will investigate the construction of memory on a social and urban scale

The first phase stresses the issues of the current use of architectural commemorative apparatuses. The process of memorialization, regardless of its context, leaves ever-changing impressions of a past, rather than faithful reproductions of it. Whether individual, collective, these impressions are often tinted narratives aiming to emphasize particular conditions from an incompatible time and space. In essence, the monumentality and permanence of commemorative architecture contradict the ephemeral nature of memory. This research, therefore, supports the subjective, plural and mutable character of historical narratives in commemorative building.

Secondly, research will become practice with a proposal for a Civic memorial on Ottawa's LeBreton Flats. Throughout history, this site has remained a central stage for Ottawa's development and debate on the preservation of the past: a key settling site for Algonquin families and some of the first European immigrants, the Flats preserved their communal nature up until the government expropriated the land in 1965 and left it vacant for nearly forty years. By designing a project commemorating the social activity and investment on this land, the thesis project will aim to demonstrate how locality is essential to the integrity of the memorial. 


\section{ii Acknowledgments}

There are a number of people without whom this thesis might not have been written, and to whom I am greatly indebted.

To my parents, who have been a source of encouragement and inspiration, a very special thank you for nurturing me through this last year and for your continuous support in my every project and the challenges they presented.

Also, my utmost gratitude to my thesis advisor, professor Yvan Cazabon, for sharing his knowledge and memories with. Each of our discussions made the navigation through such a complex topic that much more fascinating and inspiring. I am also very grateful to his colleagues, professors Roger Connah, Janine Debanné, Federica Goffi for their valuable advices and responses on the subject of my thesis. Your support was essential to the success of this research.

Finally, to my brother, Ivan, and my best friend, colleague, and "sister", Jéhanne, there are no words to express the full extent of my appreciation for all you've done for me and for the many challenges you helped me overcome. I owe you the success in this research, but also the success in the completion of my studies. With my all my love and respect, thank you for everything. 
2 Introduction

\section{I. Constructing the Collective Memory}

5 Self-Definition and Collective Identification

7 Recognizing the Past

9 II. The architectural response: the memorial or the staged memory

10 Artificial Recollection in a Changing Reality

12 Overmemorialization and Collective Amnesia

14 III. Deconstructing the monumental

15 The counter-monument: Reversing permanence, Confronting Absence Jochen Gerz and Esther Shalev-Gerz, Hamburg Monument against Fascism, 1986-93

17 Deconstructing the Collective Memory into a Collection of Memories Wall of Dominoes installation for the 20th Jubilee of the Berlin Wall fall, Berlin, 11/2009

19 Memorializing the ephemeral in a placeless place Maya Lin, Vietnam Veterans Memorial, Washington DC, 1982

22 IV. A Civic memorial on LeBreton Flats:Absent History and Misplaced Memories

27 Remembering the LeBreton Flats: Historical traces in support of the current practices

31 Diversity in the site, its memories, its people, and in its new collective identity

37 The Portrait Gallery: an informative mosaic of past milieus and their people

\section{Postscript}

\section{Bibliography}

60 Illustrations Sources 


\section{iv List of Illustrations}

\section{Case studies}

15-18 Jochen Gerz and Esther Shalev-Gerz. Hamburg Monument against Fascism. Hamburg, Germany. 1986-93.

(01) A local woman makes her contribution to the Hamburg monument.

(02) The unveiling and first four sinkings of the Hamburg Monument against Fascism. From the invitation to the ceremony commemorating the fifth sinking.

17-18 Dominoes Wall urban installation. (20th Jubilee of the Fall of the Berlin Wall, Berlin, Germany 11/09/2009)

(3) (4) (5) Dominoes, wall segment near the Reichstag, Berlin 11/09/09 @ Tzvetelina Videnova

(6) Breaking bricks, domino-style. Conceptual Model (Photographer: Berlin Partner $\mathrm{GmbH}$ )

19 Maya Lin. Vietnam Veterans Memorial. 1982. Washington D.C., USA.

(7) Vietnam Veterans Memorial, Washington DC, 1986. Photo Hu Totya

\section{Site Study}

22 General view of LeBreton Flats

(08) Aerial view of LeBreton Flats (collage of historical maps by author)

24 LeBreton Flats during the Lumber Trade Era

(9) Bridge Street looking north from Duke Street corner.

(Collection Canada document \# PA-027803)

(10) Canadian Atlantic Railway yards on Bridge St. 1893.

(Collection Canada document \# PA-029923)

(11) Lebreton and Chaudiere from Parliament Hill. 1889.

(Collection Canada document \# PA-008351)

26 Federal Governmen'st expropriation of the Flats. 1962-1965

(12) The Toronto Star reports the latest plan (June 2, 1966)

(13)Aerial View of the Flats following the Governent's expropriation. 1965. 


\section{Proposal for a Civic Memorial}

28 The Flats organization

(14) The Site, its functions, its memories (diagram by author)

\section{An Acre of Time}

(15) Phil Jenkins' Acre of Time (Bird's eye view of the city of Ottawa.1876)

\section{3-35 Ottawa's commemorative apparatus}

(16) Mapping the Monument-Mania phenomenon in time and space

(17) Commemoration of Displaced (de-contextualized) memories

(18) Commemoration of Local memories

36 The National Holocaust Monument Design Concept

(19) Nazi concentration camps: racial classification system for prisoners.

38 Remembering the site: a mosaic of moments

(20) Aerial view of the Flats (collage of historical maps and aerial photographs of LeBreton Flats)

(21) Britannia Terrace: historical solution to current circulation issues (axonometric view: integration of a past condition onto the current site)

39-40 General view of the project

(22) Site Plan

(23) South façade viewed from central lot

(24) Dwelling on the memorial's roof

(25) Site Section

41-42 Spatial relationship between the site and the space of commemoration

(26) Crossing the Memorial: a toggle between past and present (Cross Sections)

(27) House-facade shaped walls: signifiers of an absent reality, the space of the workers' homes 
vi List of Illustrations

(28) Floor plan

43-47 Experiencing the natural history of the site

(29) Geological palimpsest: encounter with the site's natural past

(30) Portaging through time: the site's past uses expressed in the structure and materiality of the project

(31) Geological palimpsest: Interior view

(32) The natural Climatic conditions: actors in the experience of memorialization. Autumn mornings, where the memorial hides in the dense fog.

(33) Great Fire of Ottawa (Collections Canada, document no. MIKAN 3363962)

(34) The natural Climatic conditions: actors in the experience of memorialization. Winter afternoons light penetrating deep into the space of the memorial.

48-52 The Portrait: a documented reflection of the past into the space of remebrance

(35) Portrait Exhibits: Juxtaposing past and Present (Interior elevation looking South)

(36) Portrait Exhibits: (re)composing the past (Interior elevation looking North)

(37) (38) (39) Interior Views 
"Through time, we have acquired an imbalance between our material and our spiritual development. Our culture - civilization is defective."

(Andrei Tarkovski, Offret (1986): Alexander, 00:21:05) 


\section{Introduction}

Societies and their urban environment are constantly evolving and re-defining themselves. History is non-dissociable from memory:

"[History] is an ever-growing collection of events past their due date. It's leftovers, the crumbs of something time ate. It's a shoebox stuffed with facts, waiting to be sorted out. But putting those facts in the right order is not always easy, because facts have hidden personalities." (Jenkins, 1996: 219)

The interdependence between history and memory draws the affinities of an individual or a group of people to the physical context they inhabit. Past events are preserved through these people's memories and the archives they produce.

Motivated by a desire to perpetuate particularly influential events in a collectively and easily accessible way through time, humans build physical reminders including memorials. Memories of a chosen past are permanently inserted into these in a changing time and space. In other words, the exploration and practice of the city today invites its visitor to know and meditate on the site's previous conditions.

The process's main difficulty lies in the fact that the associative mechanism of Memory merges two completely different realities: the past and the present:

"[The informant] is not contemporary with the event he narrates [...] the informant's account says as much about the present as it does about the past" (Augé, 1995: 9)

It is impossible to determine the exact nature of the recollection. The merger of different times and spaces creates an environment specific to the memory and is detached from any reality, past or present. On the other hand, the motives of recalling an event in a given manner are usually guided by recognizable realities or conditions: sharing memories invites individuals to regroup around similar personal experiences and backgrounds. However, since the latter are not fully graspable by the recollectors, manipulating their contents and narrative will definitely tighten the bonds that define the regrouping. In short, memories constitute impressions of a past but are not and cannot be faithful reproductions of it. When they take the architectural form of memorials, they monumentalize the ephemeral. As James E. Young, and Lewis Mumford have already 
noted, the main conflict in permanently commemorating momentary narratives is that "an image created in one time and carried over into a new time suddenly appears archaic, strange, or irrelevant altogether. For in its linear progression, time drags old meaning into new contexts, estranging a monument's memory from both past and present, holding past truths up to ridicule in present moments. " (Young, 1993: 47)

While the personal and social processes of recalling pose a barrier to the relevance of memorials, another factor proper to our era adds to these issues of recollection: over the last three decades, the information and telecommunication revolution has completely changed the treatment and use of history and memory:

"As we age and technology advances at a clip, we are painfully reminded of the increasing quantities of memory production information these media have made available to us, and of the knowledge we are forgetting possibly at a quicker rate than the technology can create." (Hornstein, 2011: 42)

The memories that previously belonged to limited groups of individuals have become available at a global scale. Local remembrances are extracted from their milieus and are now intertwined and offered as bundles of information. There is no longer a need for an immediate dialogue regarding specifics to those milieus. Researching, compiling the sources and building a digital mosaic of a context allows anyone to associate to any memory. Architecturally, that phenomenon can easily be observed with the proliferation of monuments reflecting events that have not occurred in the location where they are built in. For instance, the city of Ottawa possesses no sites that are directly connected to the Holocaust nor to Communist regimes, and yet, monuments reflecting these memories are to be erected in Canada's capital. Memorials are becoming commodities intended to feed an urban aesthetic desirous of international recognition, and various political and economic agendas, regardless of historical accuracy or contexts. Such monuments are not strongly representative of the territory in which they are erected. Rather, they present themselves as invitations to the public to become awareneof distant events and influences. 
All in all, "the notion of the monument as memorial or commemorative public event has witnessed a triumphal return." Cities worldwide have embarked in what one might term a "practice of overmemorialization," or, as Andreas Huyssen calls it, "monument mania." (Huyssen:2003, 31) With that overflow of "foreign" memories, the societies' reflection on their own history, in practice and in remembrance apparatuses, is decreasing. Following the latter observation, the following work will investigate the dichotomous process of translating the ever-changing memory into a permanent architectural form in the context of Ottawa. In order to understand the city's latent motives and building conventions of memorials, one must look into the different phases of the process of memorialization. In the first segment of this work, this thesis will investigate the formation and function of memory from its initial, individual stages to its collectivization and institutionalization. Deconstructing the process of recollection will help determine its weaknesses. These will then help clarify how memorials function within the city and influence societies. Physical triggers of collective memories aim to gather groups of individuals together under a common identity and space. However, the recent phenomenon of "monument mania" appears to have created the opposite effect. In regards to the current and future developments on Ottawa's LeBreton Flats - notably the building of the National Holocaust Monument - the preservation and respect of the site's historical integrity and influence is to be questioned. While many memorials have already introduced their distant narratives into the Canadian capital's context, an investigation of the use of the public space that surrounds and connects these buildings would allow redirecting their narratives towards a more local vision. Thus, this thesis will address a proposal for a civic memorial, with the objective to allow the local identity of the site to resurface and to reconnect the experience of the Flats to that of the city.

Following the investigation on the remembrance process, a parallel will be drawn with its architectural response. Various case studies, and elements of their designs, will provide a starting point to the proposal to "counter-monumentalize" the architecture of collective and historical memory. While the examples I will bring forward into this work reflect distinct memories and milieus, some spatial aspects evoke more abstract or broader themes that are relevant to the conditions of the LeBreton Flats and its dynamic communal past. 


\title{
5 I. Constructing the Collective Memory
}

\author{
Self-Definition and Collective Identification
}

Popular culture often depicts the memory apparatus as a tiny cabinet filled with individual memory folders in which information is stored away. Although very simplistic, this image presses on the true pluralistic and fragmented nature of memory: past events are not cognitively collected as complete entities. Stored and retrieved memories result from a complex process of de-construction and re-construction. ${ }^{1}$ Furthermore, as Sigmund Freud's early work on psychoan-

1. When two or more of the brain's hundred billion neurons meet, informationisgeneratedand transmitted throughanelectro-chemical signaling called a synaptic connection. The information produced variesand thereforeis processed differently depending on its nature. The latter will be assimilated into one of the three modes of memory,asdefined by the Atkinson-Shiffrinmodel:thesensory, short-term and long-term. What we usually think of as "memory" is a general usage of the long-term memory. However, regardless of the memory mode that is triggered by the encounter with the memorialized elements, the process only concerns fragments or details of that encounter at a time.

A second model has been developed in the 1970s by Fergus Craik and Robert Lockhart which stipulates that the extent to which something is memorized depends on the depth of the cognitive process, from a shallow, perceptual process to a deep, semantic one.

Unlikethe Atkinson-Shiffrin model,thelevel-of-processing model has nodefinite structureand does not distinguish short-term from long-term memory.However, both modelsdepict thesame process of deconstructing the memorized subject into multiple fragments of information that are stored and later retrieved individually. alysis explains, memory is a threshold between the past and the present. The recollection works alongside the repetition of past actions and experiences. Freud pinpointed the main element and issue of the memory-shaping process: repetition. The information and its manifestation are reinforced with use, over time, meaning that one's ability to repeat a certain action (and interaction) with his/her immediate environment determines the quality of his/ her memories. On the other hand, as much as the reiteration of an action or event may help conserve certain of its facets through time, the environment in which the repetition takes place and the stimuli that trigger the recollection continue to evolve. The reoccurance and recollection process practices the brain to repetitively activate targeted cells in a determined order, hence the ease of remembering. This process, however, also detaches furthermore the memory from the initial happening.

As we know, individual identities and knowledge are moulded by one's memories; however, memories' sources - the encounters and witnessed events - are never preserved the way they were initially experienced:

"Because these memories are repetitions, because they are successively engaged in very different systems of notions, at different periods of our lives, they have lost the form and the appearance they once had." (Halbwachs, 1992: 47)

Often, when one attempts to remember an event as it happened in the past, an additional social dimension is involved in the process of remembrance. As 


\section{I. Constructing the Collective Memory}

2. In his 1995 essay, titled Archive Fever: a Freudian Impression, Derrida examines Freud's notion of the "death drive" and its process of destroying "in advance its own archive as if that were in truth the very motivation of its

most proper movement" (14) Memorials aim to remind societies of past events. In doing so, they become substitutes to these memories of absen realities. In the minds of the people who read the memorials as such, their narratives replace their own memory of that past, destroy it in the process of generating a space of memorialization or a spatial archive. Built monuments act inoursocietiesasenvironmentaldeathdrivesthrough which theabsentreality isreplacedby ablurredand limited collective interpretation on the past.
French psychologist Paul Fraisse wrote in the fifties, "we are never alone [...] our most individual memories are closely dependant on the group in which we live." (Fraisse, 1957: 168) The frameworks used by people living in society determine the nature of remembrance. If the social frameworks change, memories generated through them will as well. Simply put, the way a society structures itself today determines the manner in which it engages with its past. This social structure also influences the production of physical reminders": "the technical structure of the archiving also determines the structure of the archivable content event in its very coming into existence and in its relationship to the future." (Derrida, 1996: 17)

The molding of a collective identity that can transcend the present generation therefore requires the persistence of exterior factors, of a locality. Evidently, the spaces societies inhabit change with time. There are nevertheless some conditions that conserve their influence through history. Phil Jenkins observed in his book An Acre of Time that natural resources have much more influence on history telling than human memory:

"Soil is a living mat. An ounce of the acre's dirt, hardly enough to cover a child's palm, is a nation of relationships that we no more understand than we know the people in a city we fly ove. There is no such thing as an individual in nature. Inside every seeming bit of independence, life is a colony of co-dependants." (Jenkins, 1996: 26-

27)

The natural state of the place - "noble in geographic position" (Debanné, 2005: 42-5) and dialoguing with heritage and culture on a general level - provide frameworks that might be manipulated by society, but that fundamentally keep their function in time. Whether we consider LeBreton Flats as they were in the late eighteen hundreds or as they are today, the site has maintained the geological and vegetal resources, is still advantageously situated next to the Chaudière Falls, and represents a layered threshold between the First Nations, French Canadians and the English Canadian culture and society. These unquestionable facts about the Flats, if considered in the recollection, provide a durable framework that roots the collective memory in a timeless reality. 


\title{
7 I. Constructing the Collective Memory
}

\author{
Recognizing the Past
}

3. In response to the subjective nature of collective memory, Paul Ricoeur writes about the "Histographical operation" in Memory, History, Forgetting. Need is to research and to write about history as a support and a way to correct the Collective Memory. That "corrected version" becomes what Halbwachs refers to as historical memory. Although the production of such a memory appears to be better documented and supported by facts, the latterremainarchivesthatwere produced by individuals. The operation remains subjected to thesamemisinterpretations andfalseconnections between memory fragments.
During the early stages of personal development, the child is engaged in an experience of the surrounding environment, free of social and collective constraints. As a period when humans enjoy privileged and direct contact with all the things that surround them, childhood is crucial in the process of self-identification to specific times and places. Following this period, individuals will be required to join and evolve into adulthood as part of various groups. They are born distinct individuals, but will subsequently learn the rudiments of life in a family setting and then move to larger and more varied social groups. Part of the nature of their interaction within these groups is to share and preserve common memories. Even "when people think they are alone, face to face with themselves, other people appear and with them the groups of which they are members." (Halbwachs, 1992: 49) The influence of the mass over their recollections shapes Collective Memory. As it was explained earlier, a memory is the reconstruction of an experience through impressions gathered by the interaction of the body and mind with a given subject. The multiplicity of these individual impressions and interpretations introduces a greater probability of inaccuracy in an given collective memory: If one of the many sources of outside influences overwrites the initial information, the memory will already be inaccurate. When in the sharing process everyone proposes a slightly misinterpreted recording of an event or a subject, then the collective memory distances itself even further away from the reality. Furthermore, the social constraints imposed upon group members add an extra layer of falsification to the recollection. ${ }^{3}$ The key aspect of memory resides in "its unreliability, that is to say, its selective focus". (Hornstein, 2011: 42) Most informative informative or information? sharing practices practices that always involve greater groups of people - undergo a process of homogenization and simplification to allow everyone to understand the meaning of the topic in question, regardless of personal backgrounds. (cannot put two inserted clauses -- -- in one sentence)The greater the outreach of a commemoration, the blurrier the actual memory stands in relation to its context.

In his essay titled Ideology and Ideological State Apparatuses (1970), the French philosopher Louis Althusser examines two forms of power, the Repressive State Apparatuses (RSA) and the Ideological State Apparatuses (ISA). While the first form belongs exclusively to a ruling class, the ISAs can be con- 


\section{I. Constructing the Collective Memory}

trolled from all members of a society in order to reinforce a form of dominance or discipline through ideology.

In form and process, memory appears natural to people, but in the hands of a governing class, it can easily become an instrument of discipline and power. Consequently, what societies recognize as their History often ends up being a reflection of the past tainted and injected with the ideas and ideologies of the institutions in power. With that observation in mind, are collective commemorations within the city propitious instruments for truly inviting people to remember? Can we really speak of remembering when the materials commemorated, however different at the start, "are reduced to pure signifying function as soon as they are caught by myth [or ideologies]?" (Barthes, 1991: 114) The historical background we associate with and build our collective identities on could very well become an alien material to the generation that will follow us. With that in mind, it is fair to say that collective narratives alone cannot justify and maintain a memory's relevance for a reasonable duration in time. The operation of recollection has to become part of an every-day practice. In other words, the past has to adapt to the reality of our time and anticipate our future. 


\section{II. The architectural response: the memorial or the staged memory}

If collective memories are so prone to change with time, there is evidently a problem with the urban apparatuses societies have put in place to assist in remembering:

"The material of a conventional monument is normally chosen to withstand the physical ravages of time, the assumption being that its memory will remain as everlasting as its form. But, as Mumford has already suggested, the actual consequence of a memorial's unyielding fixedness in space is also its death over time: an image crea ed in one time and carried over into a new time suddenly appears archaic, strange, or irrelevant altogether. For in its linear progression, time drags old meaning into new contexts, estranging a monument's memory from both past and present, holding past truths up to ridicule in present moments. Time mocks the rigidity of monuments, the presumptuous claim that in its materiality a monument can be regarded as eternally true, a fixed star in the constellation of collective memor ." (Young, 1993:47)

The fact that a past event can be recollected differently and indefinitely poses a serious obstacle to any attempt to build memorials. What a society considers useful and insightful in its time could lose all its meaning with the next generation. In other words, is it relevant to put as much effort in designing a space of remembrance that would almost definitely see its raison d'être devalued and unrecognized over a period of time? The past that a society recognizes as true could very easily be perceived as complete fiction by the following generation. So again, just as it is essential to preserve a contextual stability in the individual or collective process of cognitive recollection, the physical memorial should be put in conversation with the reality of its surroundings. If the space of memorialization and the space of the city become one, then city dwellers can engage with the memorial more holistically. The memorial's meaning would thus be supported by more than its aesthetics and structure. People's regular "practices" of the city and of the memorial over their lifetime would infuse the memorial with meaning. 
Winston Churchill once said: "We shape our buildings, and afterwards our buildings shape us." (House of Commons, October 28, 1943) Two years earlier, enemy bombings over the city destroyed many architectural symbols of the British identity, including the House of Commons. With those words, Churchill brought the attention to one of the main concerns with Memory revivals: whether the past should be forced to subsist in some artificial, reproduced form conceived as a celebration of the changes leading to the transformed conditions from past to present.

The process of recollection is deeply embedded in its immediate context. In order to remain relevant, the memorial needs to remain flexible to allow it to evolve with its environment. Ergo, the immutable monument is doomed to become obsolete and dysfunctional: it remains rooted in the conditions surrounding the time of its design and construction. As the memorial loses its grip over the consciousness of the population and its time, its relation to the context weakens. It is left standing as a detached, irrelevant sculptural presence. Sites like post-WWII German cities have succumbed to a phenomenon of overmemorialization of wartime. In response to Germany's memorial conundrum, the country has witnessed the rise of countermonuments: "brazen, painfully self-conscious memorial spaces conceived to challenge the very premises of their being." (Young, 1993: 27) By rejecting the form and narrative conventions of the previously built war monuments, these installations end up negating the memory itself. Rather, their existence focus on challenging the "illusion of permanence traditionally fostered in the monument. For in calling attention to its fleeting presence, the countermonument mocks the traditional monument's certainty of history." Although these projects introduce interesting formal approaches to the architecture of memorials, their lack of historical meaning produce a resistance to their fundamental function. They "paradoxically [reinvigorate] the very idea of monumental itself." (ibid: 48) Moreover, the self-destructive body - that is, the gradual disappearance of the physical memorial and the detachment from the milieu proposed an inadequacy from the start as a past-reviving urban apparatus.

The space of monuments and their German counterparts work as Foucauldian heterotopias, "capable of juxtaposing in a single real place several spac- 
11 II. The architectural response: the memorial or the staged memory

es, several sites that are in themselves incompatible." (Foucault, 1986: 26) To understand the full extent of the memorial space and its narrative, the practitioners have to distance themselves from the physical reality they inhabit. The recognition of the memory happens outside the existing conditions. Its experience and the information provided are therefore irrelevant in the shaping of a collective identity on the basis of a specific locality.

On the other hand, designing a flexible memorial presents its own difficulties as well. Depending on the essence of the change, its source and the way it influences the historical shift between the past and the present, the memorial could take the form of a space of transit: deprived from any determined context, experienced as a true moment of transition, in time and space. In other words, I suggest that memorials should be treated similarly to what Marc Augé describes as non-place. The space of recollection would stand as a place "where thousands of individual itineraries [converge] for a moment, unaware of one another". (Augé, 1995: 3) That moment is when the past is recognized. In order to bring together past and present, the practice of the memorial has to be connected to that of the site. This is where the respective forms of conventional monuments and countermonuments arechallenged: the memorial should function as a space of recalling, as well as a component in the daily practice of the site. If repetition is the key to a well-defined memory, a regular encounter with the memorial and a recognition of its relevance in the current site conditions would enhance one'sawareness of a previous state. Rather than imposing a fabricated memory, the resurfacing of an historical element could present a solution or an improvement over the current experience of the site. As a result, visitors' and residents' use of the space would be bettered alongside the development of a collective awareness of a past state. 
12 II. The architectural response: the memorial or the staged memory

Overmemorialization and Collective Amnesia

Many postmodern and contemporary thinkers have warned us about the dangers of overmemorialization. Pierre Nora observed that "the more we build monuments, the less we remember" (quoted in Hornstein, 2011: 9) while others like Andreas Huyssen went as far as to qualify the phenomenon as an obsession not to forget resulting from a crisis of history:

"It is the fear of forgetting that triggers the desire to remember, or is it perhaps the other way around? Could it be that the surfeit of memory in this media-saturated culture creates such overload that the memory system itself is in constant danger of imploding, thus triggering fear of forgetting?" (Huyssen, 2003: 17)

In any case, a striking rise in the building of memorials has indeed taken place in western cities over the last decades, as if memorials were slowly becoming the fetishes of a soon-to-be forgotten history. The real danger of this "monument-mania" is that the space of the memorial completely disregards the place it occupies in the natural and built environment. The recalled materials seem more vague and yet, at the same time, suffocating by their over-exposure. References to a past event are neither accurate nor complete. In other words, the fear of forgetting justifies the excessive building of physical reminders. The latter, as many as they are, are not linked together by meaningful paths, nor are they deeply tied to their respective sites. As a result, they tend to have a destructive effect on collective urban memory and urban identity.

In the end, rather than following an obsessive trend of reproducing a disconnected past on top of and with no regards to the current environment, societies would do better to build fewer monuments, and ones " that heighten consideration of place, that is the natural and built environment". (Hornstein, 2011: 17)

In light of this, how can a new space of recollection return the focus on the place when it is confronted with the displaced memory of another monument? LeBreton Flats, former site of a worker's community settlement, hosts today the Canadian War Museum as well as the anticipated Canadian National Holocaust Monument. Both memories of the Holocaust and the wars in which Canada participated have no direct ties to the past of the Flats. Yet they define the current reality of the site. The same way memories are enabled with the presence of 
13 II. The architectural response: the memorial or the staged memory

people, these narratives depict the history of communities (Jewish community, Canadian soldiers, Ottawan lumber mills workers, British settlers, Algonquin families). Thus, in the divergence of recalled events, a constant remains: the regrouping of individuals. If the memory of the LeBreton Flats should be celebrated, it has to take into account the diversity of its population and of its practices through time. In the current conditions, that means a recognition and connection of the different practices on the site (residential, war museum, holocaust recollection), and a celebration of this historical diversity. 


\section{III. Deconstructing the monumental}

Translating a memory into an architectural form raises the potential for concretizing the ephemeral. While remembering the past remains a process whose results are continually redefined, the memorial presents itself as a permanent urban figure. Treating the memorial as a monumental form prevents the transmitted memory from evolving and adapting to its environment. Restricting the space of the memorial to a fixed form pushes its raison d'être away, and brings us back to the fundamental question of whether or not memorials should be built in the first place. If the memorialized material is extracted from particular societal conditions, shouldn't its physical form also remain in contact with the place of the "happening"? In that matter, Heidegger pointed out in Being and Time (1927) the essence of this issue when asking, "why are there beings at all instead of nothing?"

As the following projects for memorials will demonstrate, the "beings" or the revived past events are inseparable from the conditions of their happening. The design of a memorial requires some level of indetermination to allow the memory to change in its environment: "Instead of a fixed figure of memory, the debate itself - perpetually unresolved amid ever-changing conditions - might be enshrined." (Young, 1992: 270) Consequently, the past reflected in the space of the memorial would remain re-definable, uncertain, and to some extent, closer to nothingness, so as not to impose itself on the site and the visitors. 
The counter-monument: Reversing permanence, Confronting Absence

Jochen Gerz and Esther Shalev-Gerz, Hamburg Monument against Fascism, 1986-1993

As part of an exhibition of sculptures in various public spaces in the German town of Münster (Skulptur Projekte 87, 1987), the American artist Sol Lewitt created a large block of black stone dedicated to the missing Jews of Münster, to be installed in the middle of the central plaza. Over time, graffiti-scrawls and slogans covered the sculpture, thus heightening its contrasting presence in its surroundings. Soon enough, town officials had the sculpture demolished to restore the peaceful order and aesthetics of the city: "An absent people would now be commemorated by an absent monument." (Young, 1992: 268)

The German debate over "which kind of memory to preserve, how to do it, in whose name, and to what end" (ibid: 270) convinced many artists across the

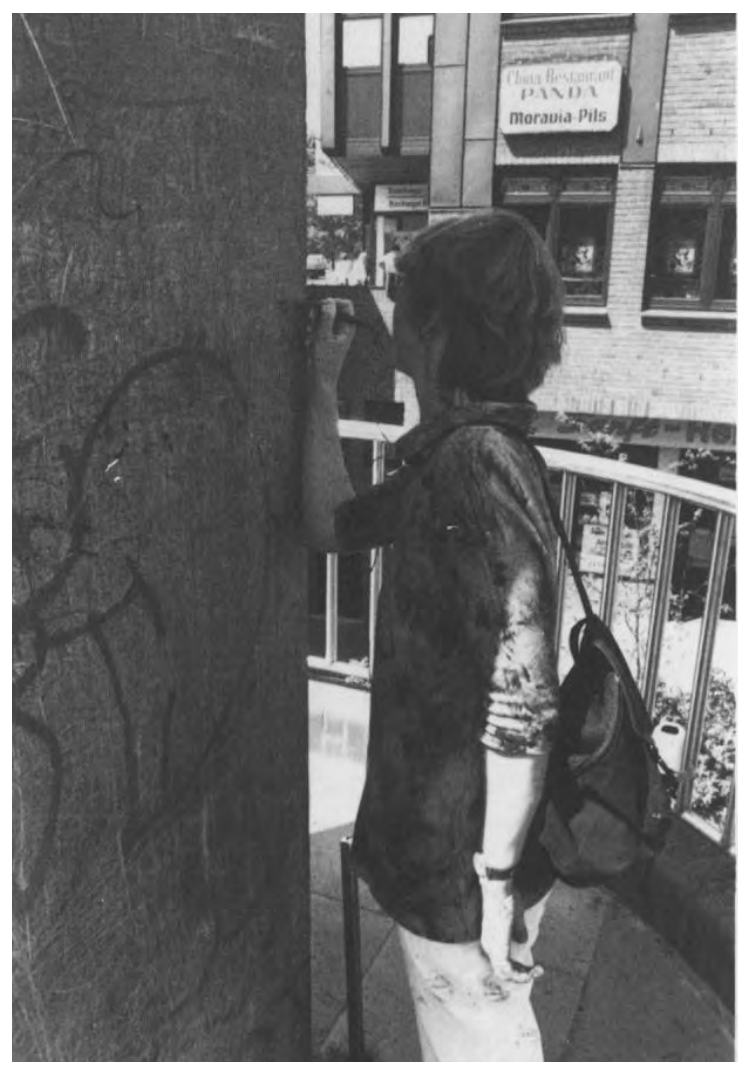

(1)A local woman makesher contribution to theHamburg monument. country to defy the conventional space of the memorial and to question "the very premises of their being." (ibid: 271) Among them, Jochen Gerz and Esther Shalec-Gerz were invited to design a monument for a town near Hamburg. Upon that invitation, their main concern was to avoid designing, as Gerz declared, one more "enormous pedestal with something on it presuming to tell people what they ought to think." (Quoted in Gintz, 187: 87)

The artists proposed to erect, in a commercial center in a suburb of Hamburg, a twelve-meter high, one-meter wide square pillar made of aluminum with a temporary inscription on its base inviting people to write down their names and thoughts on the structure. A system that gradually lowered the structure into the ground allowed the monument to disappear over time. Eventually, the massive pillar ended up covered altogether with names and other messages, thus hiding the actual structure under an ever-changing collection of inscriptions.

The architecture of the monument, in this case, functions as a canvas which, once covered with 
traces of the people who engaged with it, disappears. It becomes a structure of second importance, a support for the real memorial: the people's momentary encounter marked by an inscription onto the space of the monument, and most of all, the eventual disappearance of the memorial and the people's traces.

The project's essence and point of heightened interest resides in the period of time during which the pillar descends into the ground, hiding the inscriptions already made on its lower surface. During this process, the countermonument takes on a double identity: the visible monumental pillar, and the hidden inscriptions. The visitors who engage with the remaining part of the pillar are not allowed to experience its hidden part. They recognize the monument, but not the previous interventions made upon it. They experience the present reality of the monument in the plaza while knowing that a different one resides underground at the same time.

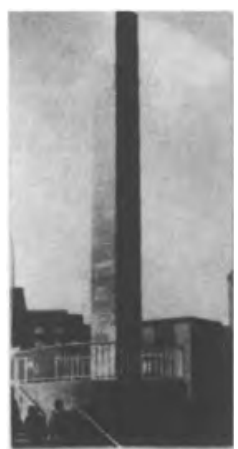

10. Oktober 1986 Einweihung

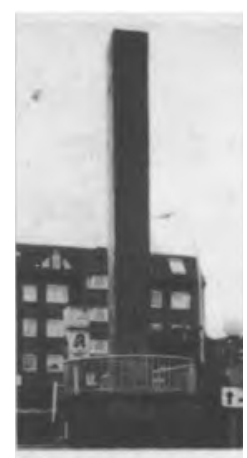

1. September 1987 1. Absenkung

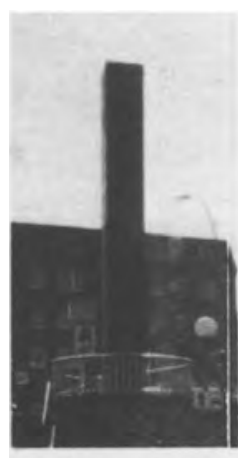

23. Oktober 1988 2. Absenkung

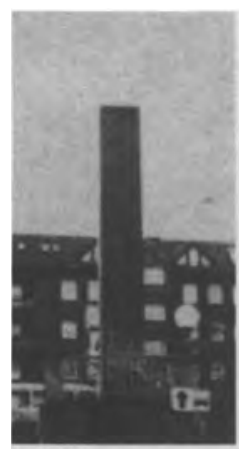

6. September 1989 3. Absenkung

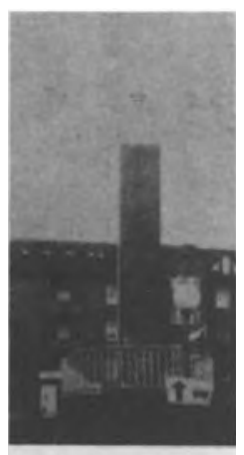

22. Februar 1990 4. Absenkung

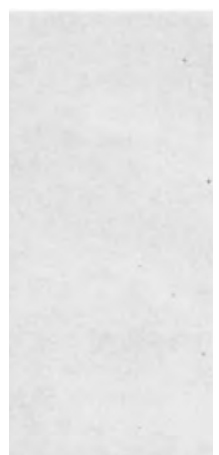

4. Dezember 1990 5. Absenkung

(2) The unveiling and first four sinkings of theHamburg Monumentagainst Fascism. From theinvitation to the ceremony commemorating the fifth sinking.

Staging a dual experience of the memorial architecture makes the visitor aware of the simultaneous present and absent conditions and their impact on the reality of the site. This operation could take place as a manipulation of forms that recalls a past context that extends in the current practice of the memorial and the site. The sculptural presence would be supported by its functional absence, and vice versa. 
Deconstructing the Collective Memory into a Collection of Memories

Wall of Dominoes urban installation for the 20th Jubilee of the Fall of the Berlin Wall Berlin, November 9th, 2009.

The commemoration of the Twentieth Jubilee of the fall of the Berlin Wall led to a reinterpretation and reproduction of its massive dividing presence. Since the memory of the fall of the Wall is as significant in History as the Wall itself, the memorialization culminated with a symbolic tearing down of the commemorative wall.
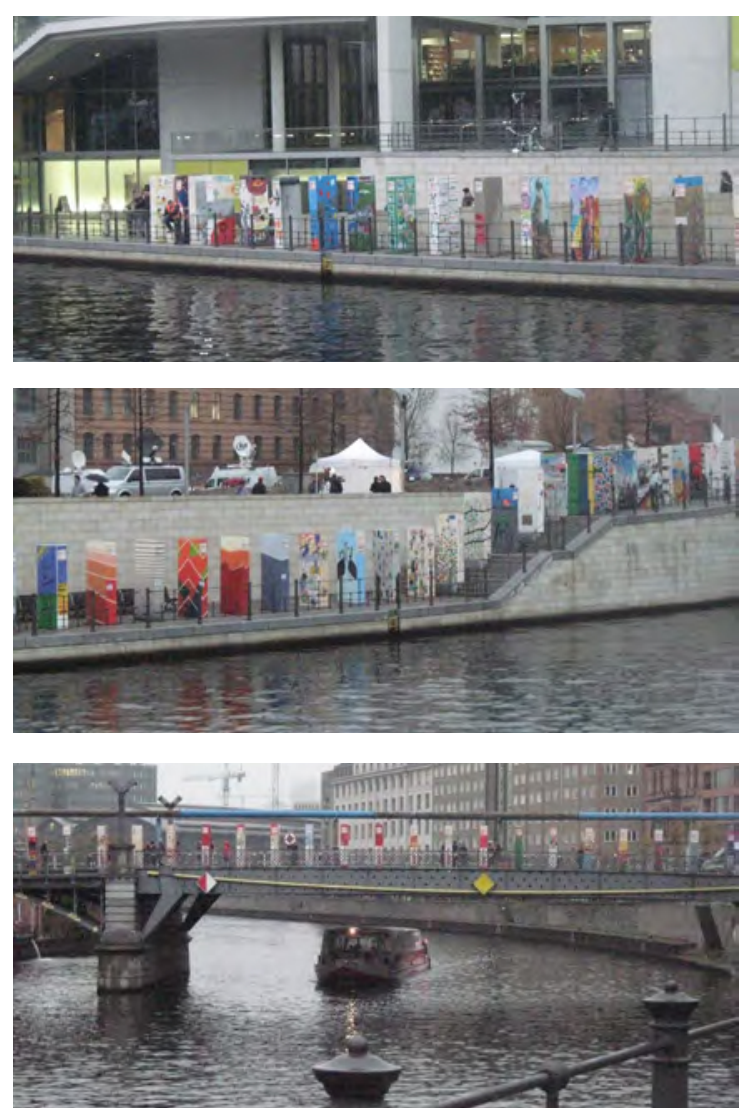

(3)(4)(5)DominopiecesinstallationneartheReichstag,Berlin11/09/09 (C) Tzvetelina Videnova
The memorial for the event's 20th Jubilee is constituted of one thousand two-meter-high dominoes. The pieces were set on the path followed by the former wall. Berliners and other people were invited to paint their individual take on the event. Each domino, while undergoing the process of being covered by a painted reflection of the people's individual memories, became an archive of the past event. On November 9, 2009, the same massive figure that divided the capital twenty years ago was reconstructed with a sequence of memories related to the site (Berlin), the form of the memorial (the Wall), the moment it changed (the Fall) and the people whose lives this event impacted (a sample of one thousand among them). The idea behind the dominoes was even more symbolic in that regard when the fall of the wall was re-enacted. The "domino effect" of the fall emphasized the plural nature of the Collective memory: each domino illustrating one individual's memory fell individually but on the process caused the next memory to fall.

At the end, what the installation really showed was that the historical event exists as a mosaic of memories, and that in the present time, reviving the fall of the Berlin Wall essentially means reviving the fall of the multiple memories of the Berlin Wall. While staging occasions for individual participation in collective memory, the structure's fragmented nature 
18 III. Deconstructing the monumental

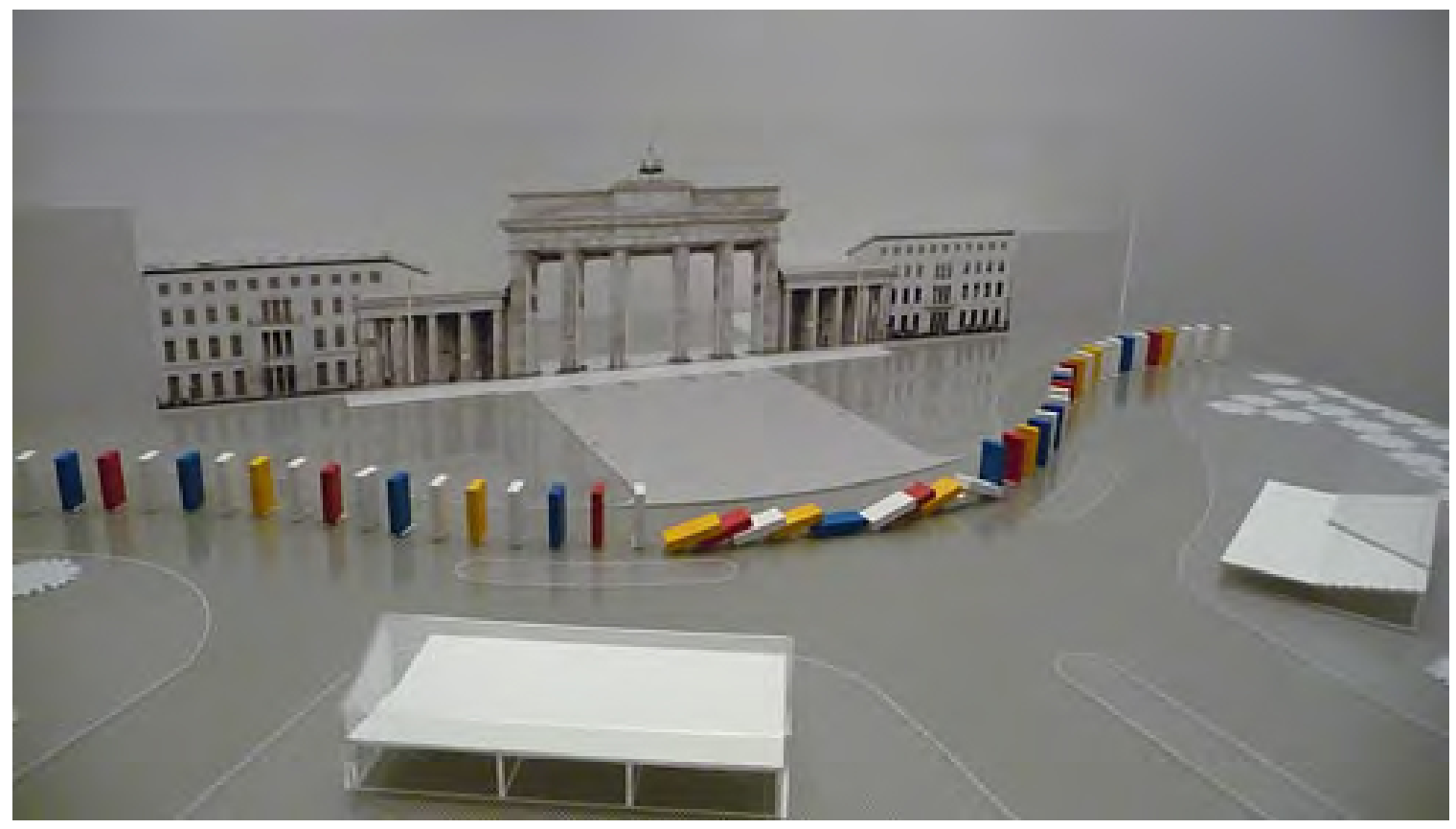

(6) Conceptual Model: Breaking bricks, domino-style.

vividly expressed the pluralistic nature of recollection itself. The experience of the installation therefore opens to multiple personal experiences and interpretations of the revived event. As fragments, the practice shifts towards the individual scale of the event. As a whole, it reflects the past of a society and a nation. The structure promotes the liberty to reshape the narrative as if the visitor was actually moving through the time and space occupied by the subjects/authors of the fragments. 
19 III. Deconstructing the monumental

Memorializing the ephemeral in a placeless place

Maya Lin, Vietnam Veterans memorial, Washington DC

Sometimes, the architecture of memorials is not intended to change over time, but its materiality encourages the visitors to engage further in the process of memorialization.

One of the most striking monuments in the last decades, the Vietnam Veterans Memorial, designed by the architect Maya Lin, was inaugurated in 1982. The monument's simplicity is stark: it presents the names of 58,000 Americans who died in the Vietnam War on a polished mirror-surface stone. The visitors are invited to see and consider themselves in direct relation to the names of those

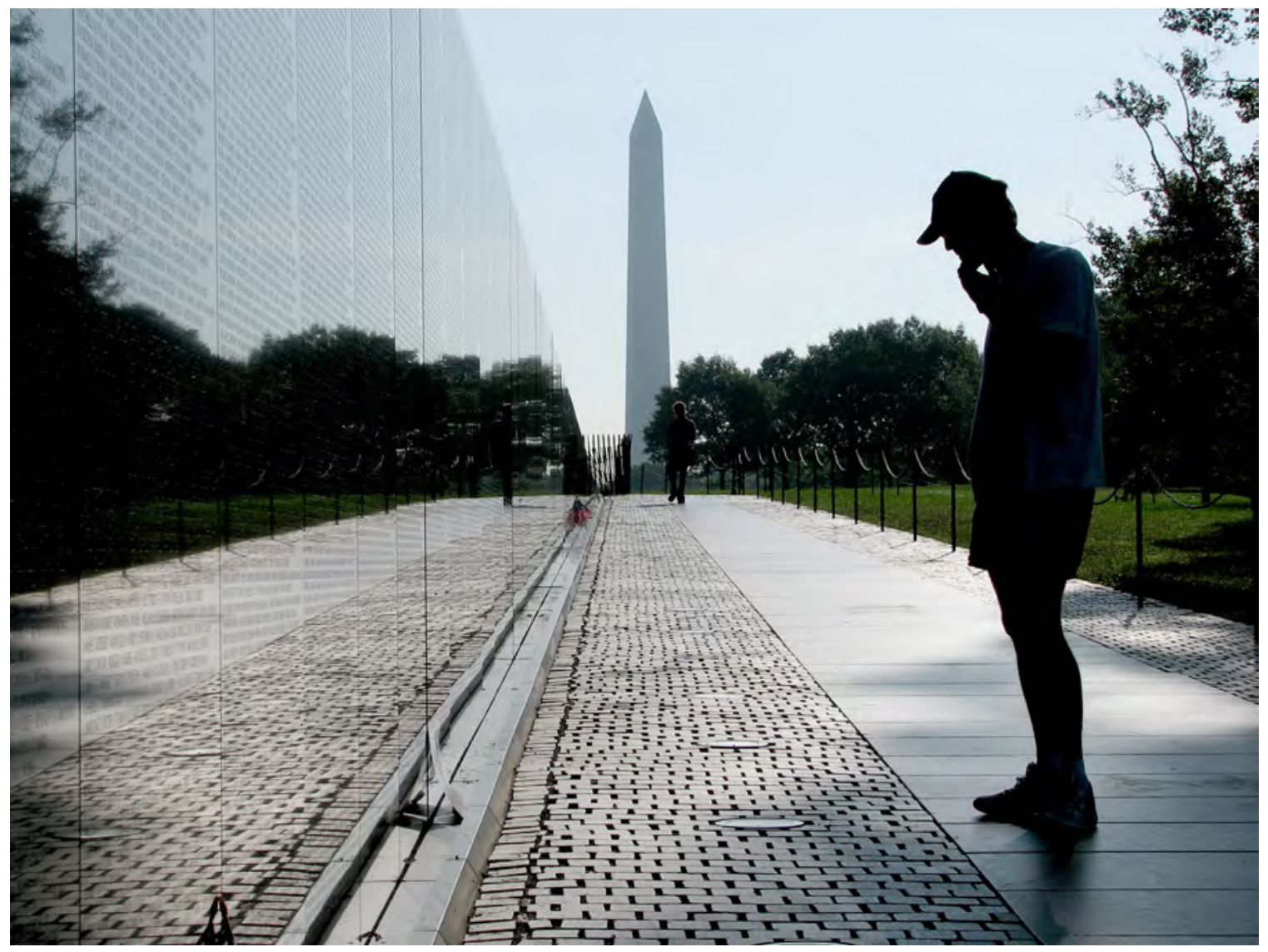

(7) Vietnam Veterans Memorial, Washington DC, 1986. 


\section{III. Deconstructing the monumental}

who passed away. The surface of the memorial merges present and past, in a manner that allows the memorial the potential to change and to evolve. The experience of the space is personalized to each visitor with the confrontation of his being with the 58,000 others who shaped the outcome of the war some forty years earlier.

Although Maya Lin's project has a continuous monumental form, its pluralistic nature is induced by the collection of names - most common signifiers of individuals. Juxtaposing the reflection of the site on the mirrored surface, Maya Lin's project produces a place of recollection that neither belongs to the present or the past. As Foucault observed in his essay titled Of Other Spaces:

"From the standpoint of the mirror I discover my absence from the place where I am since I see myself over there. Starting from this gaze that is, as it were, directed toward me, from the ground of this virtual space that is on the other side of the glass, I come back toward myself; I begin again to direct my eyes toward myself and to reconstitute myself there where I am. The mirror functions as a heterotopia in this respect: it makes this place that I occupy at the moment when I look at myself in the glass at once absolutely real, connected with all the space that surrounds it, and absolutely unreal, since in order to be perceived it has to pass through this virtual point which is over there." (Foucault, 1986: 24)

The suggested spatial threshold between the revived past and the current reality becomes a place of meditation, a canvas for the visitor's thoughts about their current experience. With the distancing of that place, they are allowed to analyse more attentively the matter that they are remembering and the implications or influences in the present time. 


\section{III. Deconstructing the monumental}

Regardless of their singular nature, these three projects demonstrate the common idea that "what history ultimately tries to explain and understand are men. The past from which we are removed is the human past. In addition to temporal distance, therefore, there is that specific distance which stems from the fact that the other is a different man." (Ricoeur, 1965: 28). Although the memorials originally give an impression of monumentality, they are incomplete without the presence of visitors. The visitors provide significance to the structure, and with every new encounter, a new personal significance manifests its influence on the memorial. The primary nature of the memory results from interventions of a human nature and scale (hand written inscriptions on the Hamburg Monument Against Fascism, individual paintings on human-height dominoes in Berlin, fullscale reflections on the monument in Washington). These interventions are as ephemeral as an individual's impact on history: they last the time of one's visit and then the memory shifts towards a new definition. Basically, the de-monumentalization of these memorials stems from a commemoration of the undetermined and ever-changing variable in history: people and the societies they form. 


\section{IV. A Civic memorial on LeBreton Flats: Absent History and Misplaced Memories}

In the rather short but fascinating history of Ottawa, there is a piece of land, known today as LeBreton Flats, which played a crucial role in the development of the city and its population. Throughout the years, the site's unique qualities invited to its exploration and occupation. With every new settlement, collective memories were shaped and the foundations of a Canadian identity were installed.

Long before the European exploration and colonization of the North American continent took place, Algonquin people were already occupying this territory and coexisting with its particular conditions. They subdivided the land among them and organized their lifestyle and agreed on social frameworks guided by the natural context of the Flats. ${ }^{4}$ Its closeness to natural resources, its particular location, the proximity to a natural source of energy (the Chaudière Falls) and a route for transportation and trade (the Ottawa River), the site was strongly coveted by the First Nations, particularly the Kichesippirini and the Weskarini tribes (Algonquin). Evidently, British and French explorers would later recognize the same opportunities the land had to offer (8) Aerial view of the site (collage of historical maps and aerial photos from 1874 to 2014) and would compete for the occupation of the latter.

Very early in the Canadian history, the site would become a threshold between the country's three dominating communities: the First Nations, the French Canadians, and the English Canadians. As the Ottawa River delimitated the frontiers 
23 IV. A Civic memorial on LeBreton Flats: Absent History and Misplaced Memories

between Upper and Lower Canadas, the site directly connected to Ottawa's first built bridge, the Union Bridge, which would act as a transitional space between distinct identities, cultures and lifestyles.

While Ottawa had been growing for some time, it was only after the War of 1812, between the North American British Colonies and the United States of America that its development would boom. In an attempt to profit from rumored plans of extending the canal up to the Flats, Captain John LeBreton purchased the site from Robert Randall ${ }^{5}$. Even if he failed to resale the land in a rising market, LeBreton would make profits with the land a few years later, when he sold the virtues of the land to businessmen and other settlers:

"The Situation is most beautiful and salubrious, being on the south side of the Chaudière Falls, with the Grand Union Bridge abutting on the centre of the front and leading through the main street. It is replete with mill sites, and for commerce, no situation on the River Ottawa can equal it. The subscriber is determined as much as possible to confine his sales to persons of respectabilit." (Last paragraph of the newspaper advertisement put by John LeBreton to encourage the purchase of lots of his subdivision. Quoted in Jenkins, 1993: 123)

From that moment on, the community living on LeBreton Flats supported the rise of the lumber trade industry and played a defining role in establishing Ottawa's economical influence and power. From the middle of the nineteenth century up to the mid-1960s, the site was home to a mixed community of lumber mill workers and owners as well as other merchants and business owners. Soon, a rail line was built with a station and yards. Consequently, other industries developed nearby. The area strived through the lumber trade era but all this brutally came to an end in the 1960s. The Canadian Government raised concerns with the unappealing presence of a blue-collar community near Parliament Hills. As a result, they took corrective action and between 1962 and 1965 the Flats were cleared from any evidence of a previous occupation. 


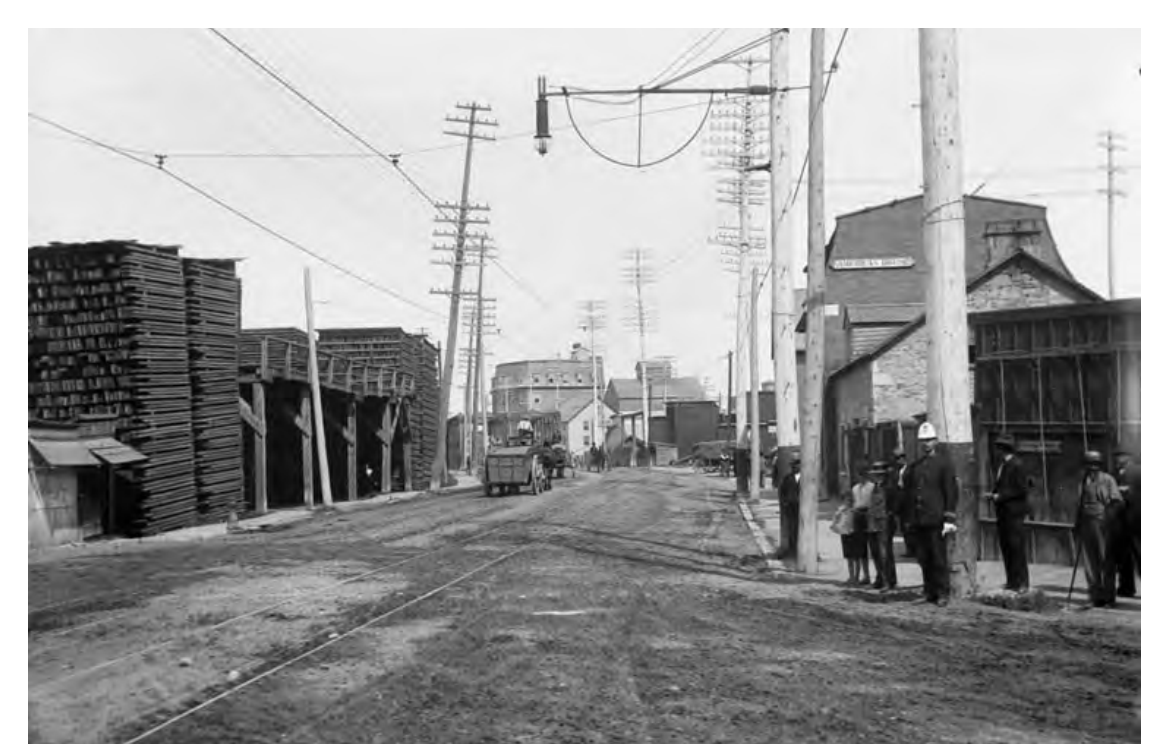

(9) Bridge Street looking north from Duke Street corner.
(Collection Canada document ${ }^{*}$ PA-0278033)

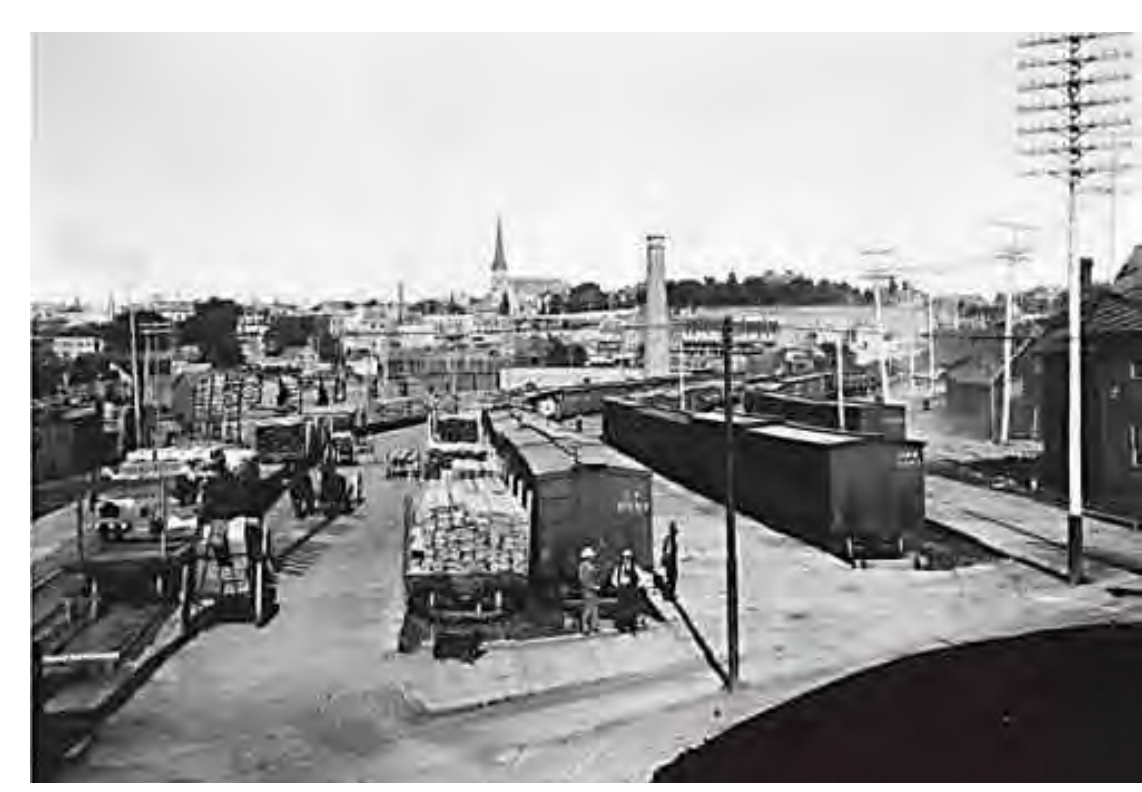

(10) Canadian Altantic Railway vardd on Bridge St. 1993
(Collection Canada doccument $\$$ \$A-2029233)

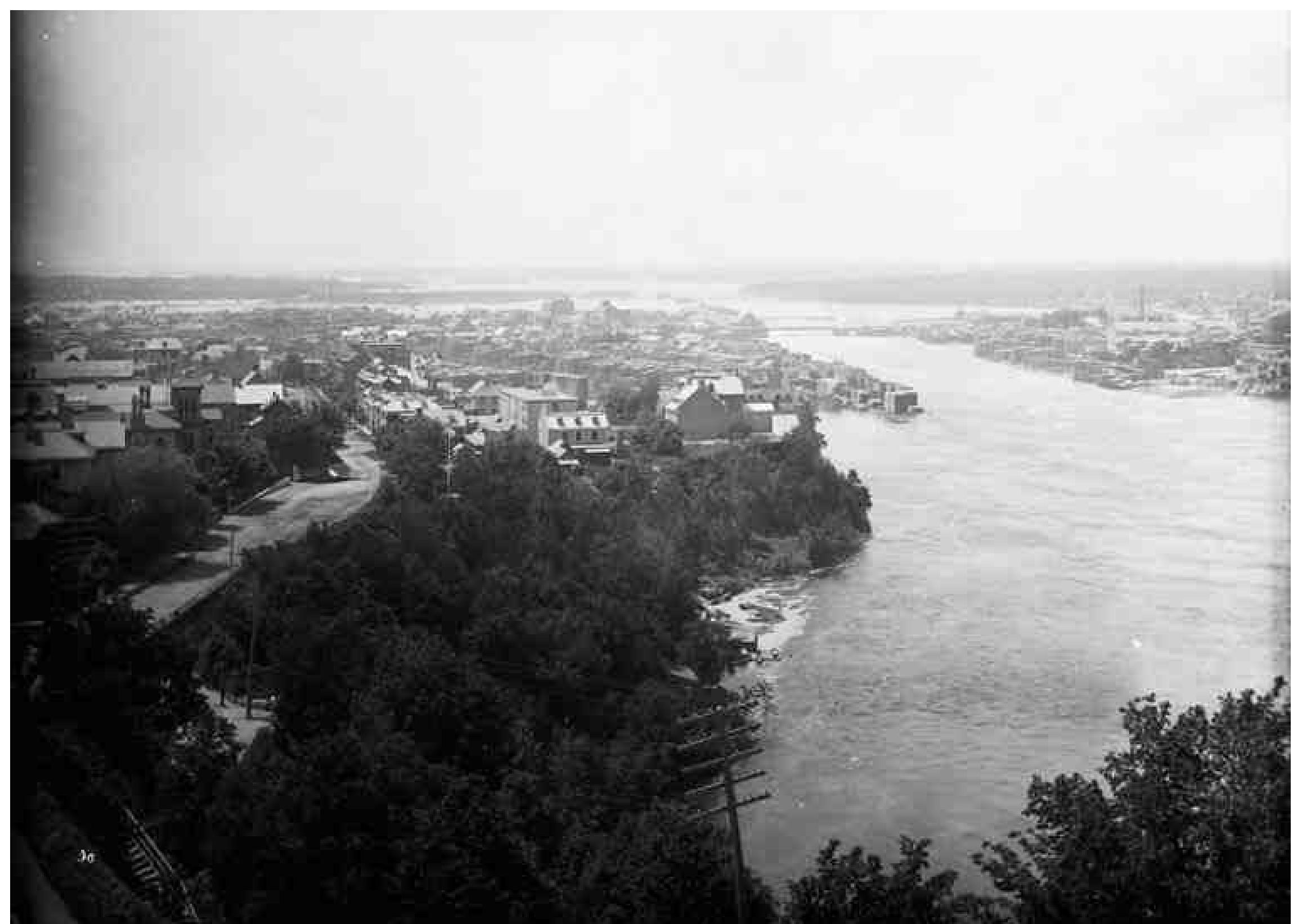

(11) Lebreton and Chaudiere from Parliament Hill 1889. (Collection Canada document ${ }^{*}$ PA-008351) 
25 IV. A Civic memorial on LeBreton Flats: Absent History and Misplaced Memories

Originally, the 160-acres site was intended to be the new seat for Canada's Department of National Defence Headquarters. Instead, military planners decided to locate alongside Colonel By Drive. For nearly forty years, every imaginable schemes has been pitched for the site. Plans have ranged from theme parks to office buildings to residential developments. In the past two decades alone, there have been proposals to build a $\$ 70$-million aquarium, a $\$ 100-$ million railway terminal for a high-speed train that would link Windsor to Montreal and a \$700-million overhaul of the Flats to bolster Ottawa's bid to host the 2005 World Fair. Proposals for the Flats multiplied like Hydra heads, Jenkins says. "Each time a plan was axed two more would sprout in its place." (Jenkins, 1996: 199) In the early 2000s, the re-development and re-dynamization of the Flats finally begins.

At the moment, residential projects are under construction on the South side of Wellington Street. The plot west of the war Museum, across Booth Street, has been chosen as the site for the Canadian Holocaust Monument, expected to be delivered by the end of 2015. An O-Train station will be implemented near the residential complexes, as part of the east-west additional line to the O-Train network. Finally, Windmill Development Group will also be working on the re-development of the Isles North of the Flats. In short, in the years to come, the site will go back to a more central, community-driven, dynamic identity.

All in all, the history of the LeBreton Flats has shown us that the conditions of this site have given it an extraordinary value. Throughout the years, the land has continually attracted people to explore, settle, live and grow communities upon it. People and buildings have occupied, evolved and disappeared on the Flats until no traces of all these years of industrialization and trade were left. What was essentially present in 1965 is what could have been seen some 150, 200 or 2000 years ago, and is what is perceptible now: exceptional natural conditions and infinite opportunities. 
(12) The Toronto Star reports the latest plan (June 2, 1966)

(13)The site in 1965 , following thegovernmentexpropriation of the land. A century of activityanddevelopmenttowards the strenghtening of Ottawa's economyandworkerscommunity waserasedfrom thecityin less than three years.
Neto Ottawa building Defence HQ may cost $\$ 100$ million

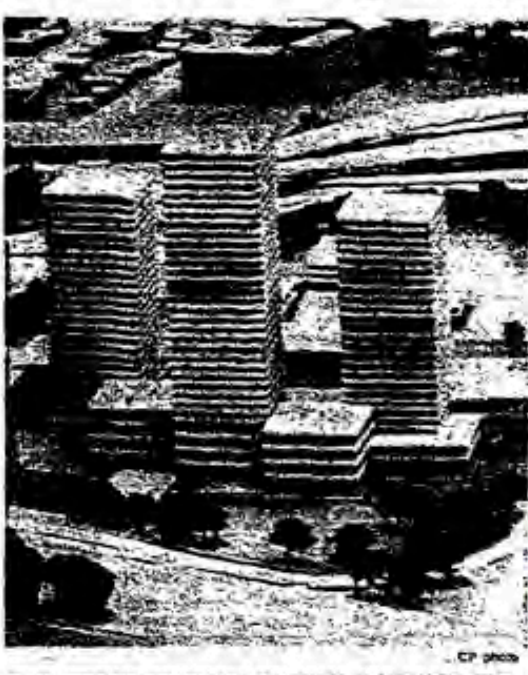

THE THTEE TOWERS OF NEIV DEFENCE H. Tallest will be 430 fret-IS stureys.
OTTAWA (CP) - A Des lowes aLl semenmudate

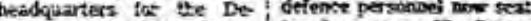

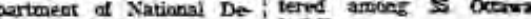
fence Nith three twers buidings. ane 3 storeys high-will be bailt bere, Worts Minister The defesce department originally antousced that bat this was belore the thiree-trumer coscret was arrived at. The cost may rus to $\$ 100$ miltion.

Coestruction is sehedule to start in 1958 and te completed in 1972

The main tower will be 450 leet high and the trot side towers will each be $x$ feet or 3 storess bigh.

The Peace Tawer. now the tallest building in the capital, is asl feet hish.

The nere departroent vthich will bouse B.000 persons, with be beilt in we fartier sina area known as minetar Fats. about one mile west of the Parliamen Buijdict the slum ha

ter Eacien Cath

Seductiontry earns him

year in jail Special to The Sear Qunvure- Nachsteste K. Ir. Landon today caber "a menace to societe" and sent him to a refomente

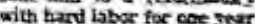
definite and ace rear into nite for altemption to

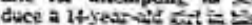
apartment

The count must aresce strate that soctec oril $x$ trilerate sucb seriots explot. Latian of a young fert." the magistrate told Coorze Stickel

Stickel sayd be jicked un the sint and a itrearold companion on the coven Elizabeth Wxy. Ife sudid When they toud tim thes were runaing awav lron

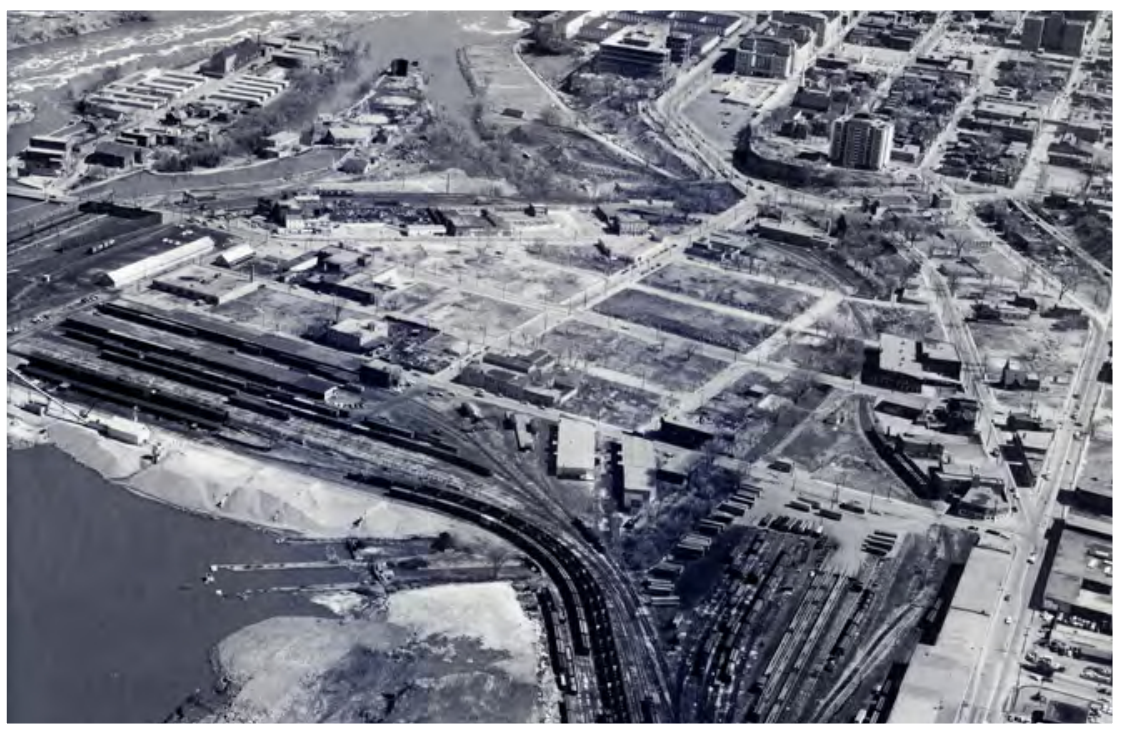


27 IV. A Civic memorial on LeBreton Flats: Absent History and Misplaced Memories

Remembering the LeBreton Flats
Historical traces in support of the current practices

When looking back at the history of LeBreton Flats, the confrontation between a dynamic past and recent nothingness stands out. With nearly half a decade of vacancy, the memory of the land and its people has almost vanished from the current city and its population. In forty years, society has changed tremendously; new generations took over, and the people who used to work in the mills and live on the Flats retired elsewhere or passed. No one was left to share the memories of the LeBreton community. The lack of physical traces forces one to realize that the absence or the nothingness also participates in the shaping of memory. Today, new buildings and functions are being implemented on the Flats. Plans for a dense and dynamic community are put into action. Still, memories of the past should be preserved.

In the midst of all these changes, a portion of the site was left untreated. North of the site of the Holocaust Monument and East of the War Museum, stands Phil Jenkins' Acre of Time. The plot is at an ideal location, acting as a cultural, linguistic and functional threshold in the site and in the city. One could even argue that the location alone celebrates change: The site sits at the intersection of two urban milieus: the early 1900s industrial urban fabric of the Vieux Hull and the Isles, and the contemporary re-development of the Flats. It stands as blurred in-between-two-eras of time and space.

At the very least, visible historical traces would make the inhabitants and visitors aware that, regardless of this forty-year break in the occupation of the land, their status in the city is intrinsically connected to that of its former inhabitants. In order to do so, the space of recollection has to function as a space of archaeological and historical digging without distancing itself from the current milieu.

As mentioned earlier, LeBreton Flats are currently structured around three main functions. The first, residential, perpetuates the image of a collective diversity living on and invigorating the site. The following two, the war museum, and the recollection of the Holocaust, although disconnected in their contents from their context, also engage with the notions of diversity, community and local identity. 


\section{IV. A Civic memorial on LeBreton Flats: Absent History and Misplaced Memories}

Rather than pushing away the displaced memories, the civic memorial should embrace the current conditions and integrate their narratives into that of the Flats' occupancy. The diversity of people has always been a key quality in the past communities and practices of the Flats. The only difference is that it has now shifted from the individuals to the urban environment. Therefore, instead of implementing a monumental figure that imposes a unified experience to the population, the space of recollection should, in its form and function, suggest a unity of the site, and a coexistence of its current functions. In other words, the space of the memorial intervenes on the day-to-day practice of the site; the distant heterotopia is reabsorbed in the milieu.

We've seen earlier that the location of the Flats within the city's territory has always been an incentive to its occupation and development. With the evolution of the population's lifestyle and distance from the workplace, the site now hosts some of the busiest routes in the center of the city: Booth Street and Wellington Street and since very recently, Preston Street. In fact, the automotive circula-

(14) The Site, its functions, its memories

Wars (2005 - )

Canadians during wartime Holocaust (2015 - ) Canadian Jewish Community
Home (-1965 / 2001 - )

Living on the Flats 
tion reaches such high densities throughout the day that it sections the site into three fragments. Circulating from one plot to another gets overwhelming when the road network is not really suited for pedestrians and cyclists. In addition, parking is only made available to the condominiums residents and the museum visitors. In short, the current conditions of the Flats are not inviting to the pedestrian. People simply pass by it by car or view it from a distance, from their apartment.

Since there is no real possibility to change the traffic of cars and public transportation in the surroundings, the intervention needs to respond to the manner in which pedestrians and cyclists occupy and move through the site. Constructing a structure above the ground would go against the argument in favour of the preservation and valorization of the visible natural conditions, thus including the views of the cities of Gatineau and Ottawa.

"To walk is to lack a place. It is the indefinite process of being absent and in search of a proper." (De Certeau, 1984: 103)

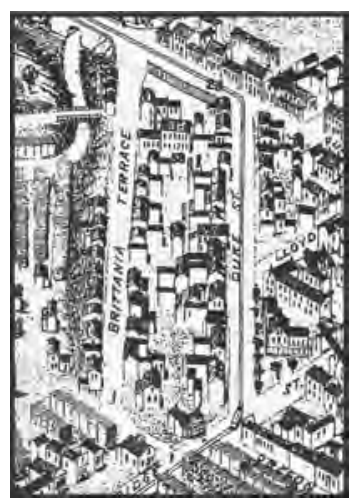

(15) Phil Jenkins' Acre of Time (Bird's eye view of the city of Ottawa.1876)
When looking at maps from the nineteenth century up until 1965, it appears that all three functions and their plots were connected by a single street: Britannia Terrace. In fact, the acre Phil Jenkins so thoroughly studied in his 1996 book was delimitated by the former street on the north, and by the former Duke Street on the south. What the memorial suggests is that a street that was mostly utilized by nearby residents as a communal space, a place of encounters or exchange, should act similarly in the current context. Thus, reintroducing Britannia Terrace on the site would support engagement without a car. Treated as an underground street, the latter leaves a rather subtle presence on the site, allowing it to evolve its own way. The space beneath the ground influences the site in two ways: First, it supports the present uses, directly connecting the land with no interruption by car traffic. At a larger scale, it also acts as an unobstructed connecting passage between Gatineau and the islands, and the Ottawa's downtown core. Secondly, it provides a basis of historical conditions to engage the visitor in a dynamic recalling process - staged as a part of the city rather than an isolated self-referential entity. The permanence of the memorial is in this case recommended, in order to allow its safe use as a transition in space and in time. 


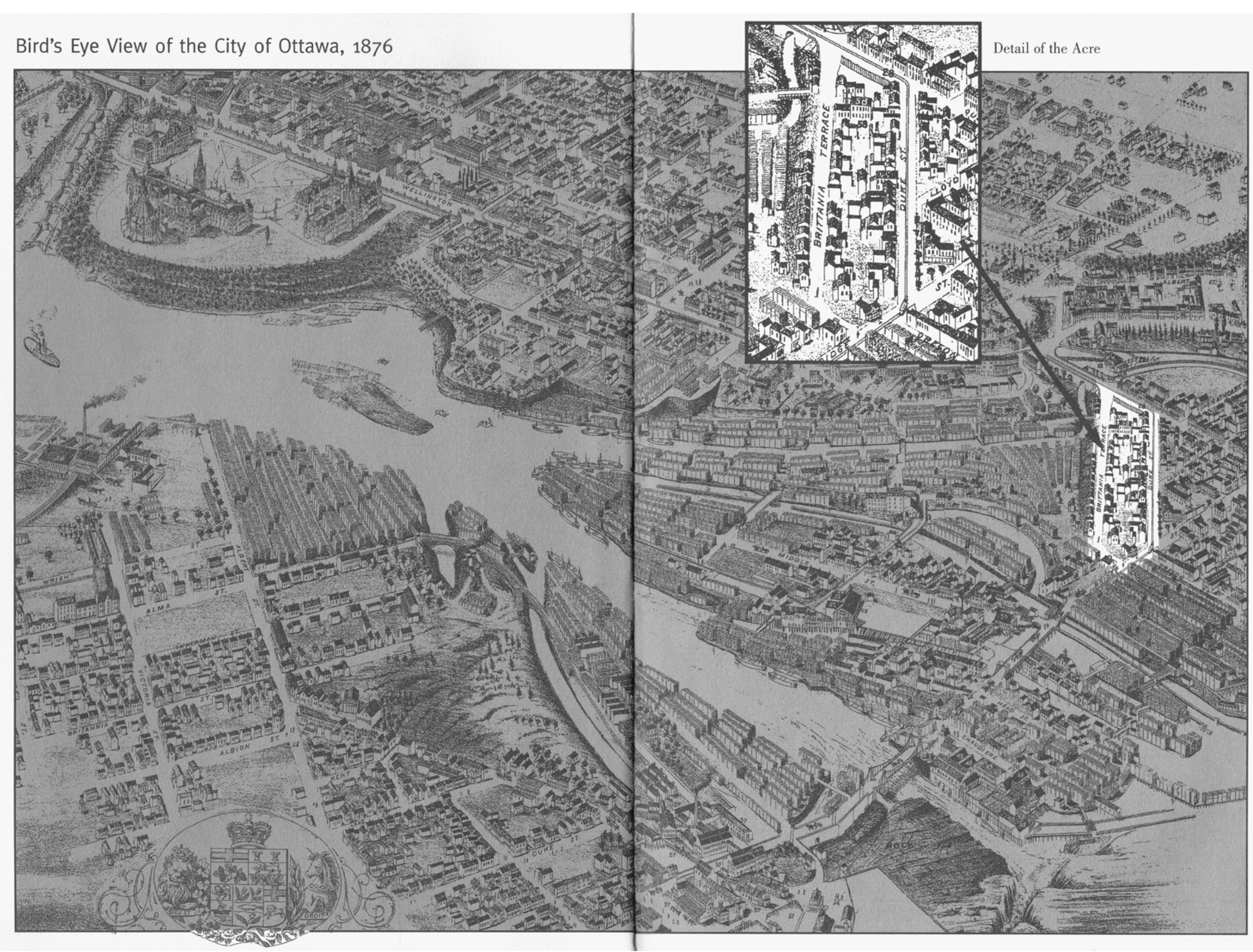


31 IV. A Civic memorial on LeBreton Flats: Absent History and Misplaced Memories

Diversity in the site, its memories, its people, and in its new collective identity

As introduced earlier, buildings such as Holocaust memorials have outgrown their initial purpose, which was to preserve and share the traumatic memory of a community during the war period. Remembering events and learning from mistakes committed at the time constitutes half of the memorial. The latter is designed with the intention to communicate a happening that occurred at a time, but also in space. Locality therefore should be respected in the staging of the memorial. During the fall of 2014, the winning entry for the future Canadian National Holocaust Monument was announced. To no surprise, a well-known figure in the design of memorials was selected: Daniel Libeskind. The firm's previous designs for the Jewish Museums in Berlin, Copenhagen and San Francisco demonstrated a clear intention to preserve the unique character of the Jewish communities in their respective environments. From the museums' forms, to their siting and their interaction with key historical buildings, all three projects unfold in the cities with the utmost attention to the specificity of local Jewish history and identity.

The proposal for the Canadian National Holocaust Monument breaks from Studio Daniel Libeskind's tradition to work with the locality and unique identity of the city and its communities. The motives and functions of such buildings are changing, as the main page of the official website states: "Canada is the only allied nation without a Holocaust Monument in its capital. This is changing." (holocaustmonument.ca, 10-04-2015)

The site selected to host the monument is located west of the National War Museum, on LeBreton Flats. Although the Flats may not appear as deeply connected to the city's past, as they truly were, they reflect an even smaller implication in the events surrounding the Second World War and the Holocaust. Considering the fact that we live in the national capital, the presence of monuments and other memorials commemorating the country's participation to the wars is understandable. To situate the War Museum on a site that had previously housed worker's settlements for about 150 years makes sense: after all, large proportions of the soldiers who fought for the country in the different Wars belonged to the working class. It is almost inevitable that some of them actually lived on the Flats when they enlisted for the army. 
On the other hand, LeBreton Flats, or even Ottawa in general, are not known to have had much of an impact on the events surrounding the Holocaust, unlike countries such as Germany or Denmark that significantly influenced the situation's outcome. The de-contextualization of the Canadian National Holocaust Monument serves to show the extents of political and economic influences over the collective memorialization. Besides, memorials and the Shoa have been exploited to such a degree in the western countries, that the collective memory has grown into a global one, independent from a site, a community, and a local history. The memory of the Holocaust has become the signifier of a society "which never forgets its past, but which more often than not does not understand it." (Young, 1993: 113)

Ottawa is not afflicted to the same extent with the phenomenon of "monument-mania" and collective amnesia that the German capital launched in the aftermath of WWII. The situation of our nation's capital however still raises serious concerns with its treatment of collective memory. The Canadian Heritage official government website informs us that, in Ottawa, of the twenty-six official monuments already built and the two announced (the Holocaust monument on LeBreton Flats and the Memorial to the Victims of Communism besides the Supreme Court of Canada), seventeen are related to Wars. Two thirds of the history reminders we encounter in the city narrate exceptional events that more often than not took place outside the Canadian territory, and with an overall very limited involvement from the Canadian population. 


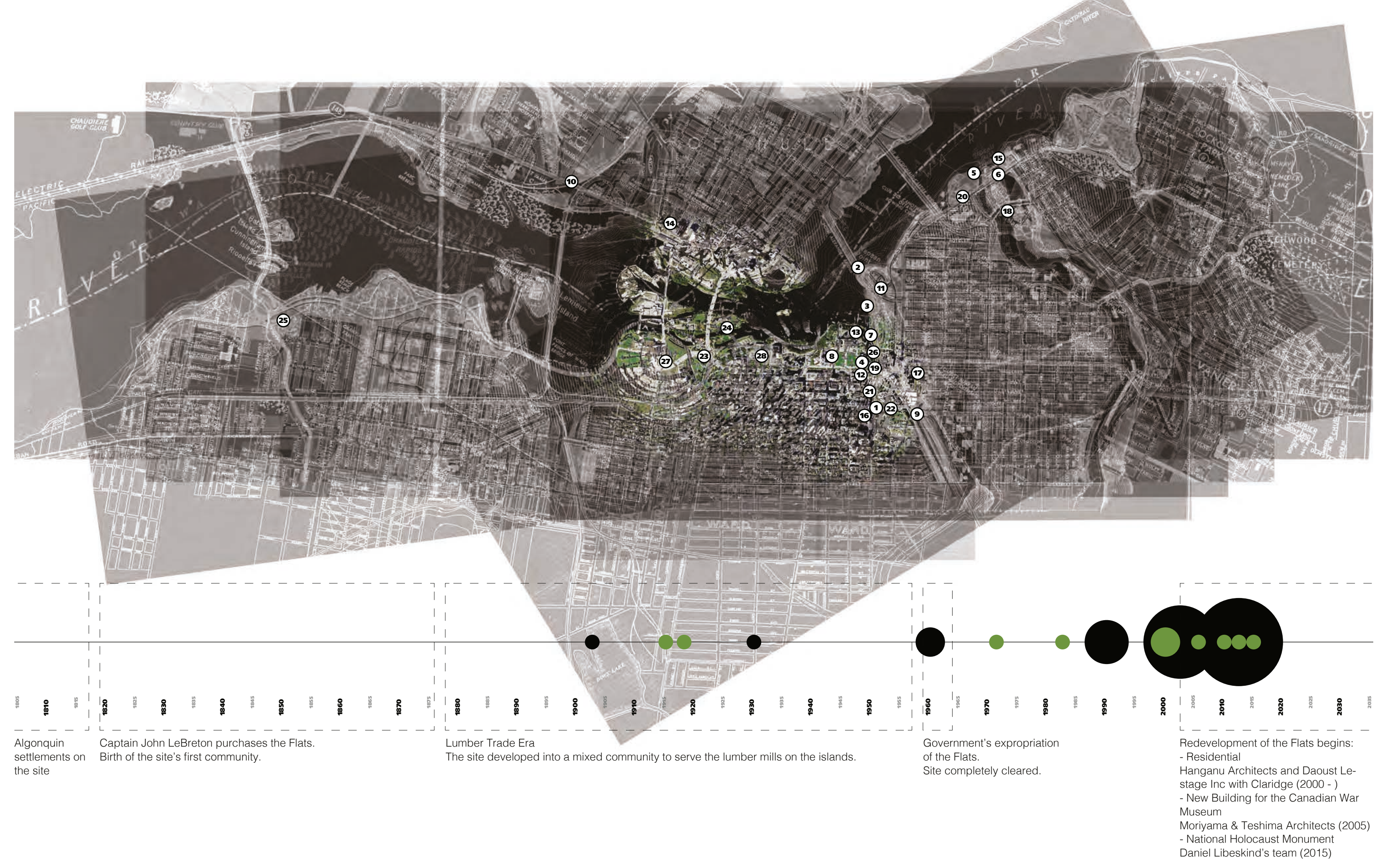




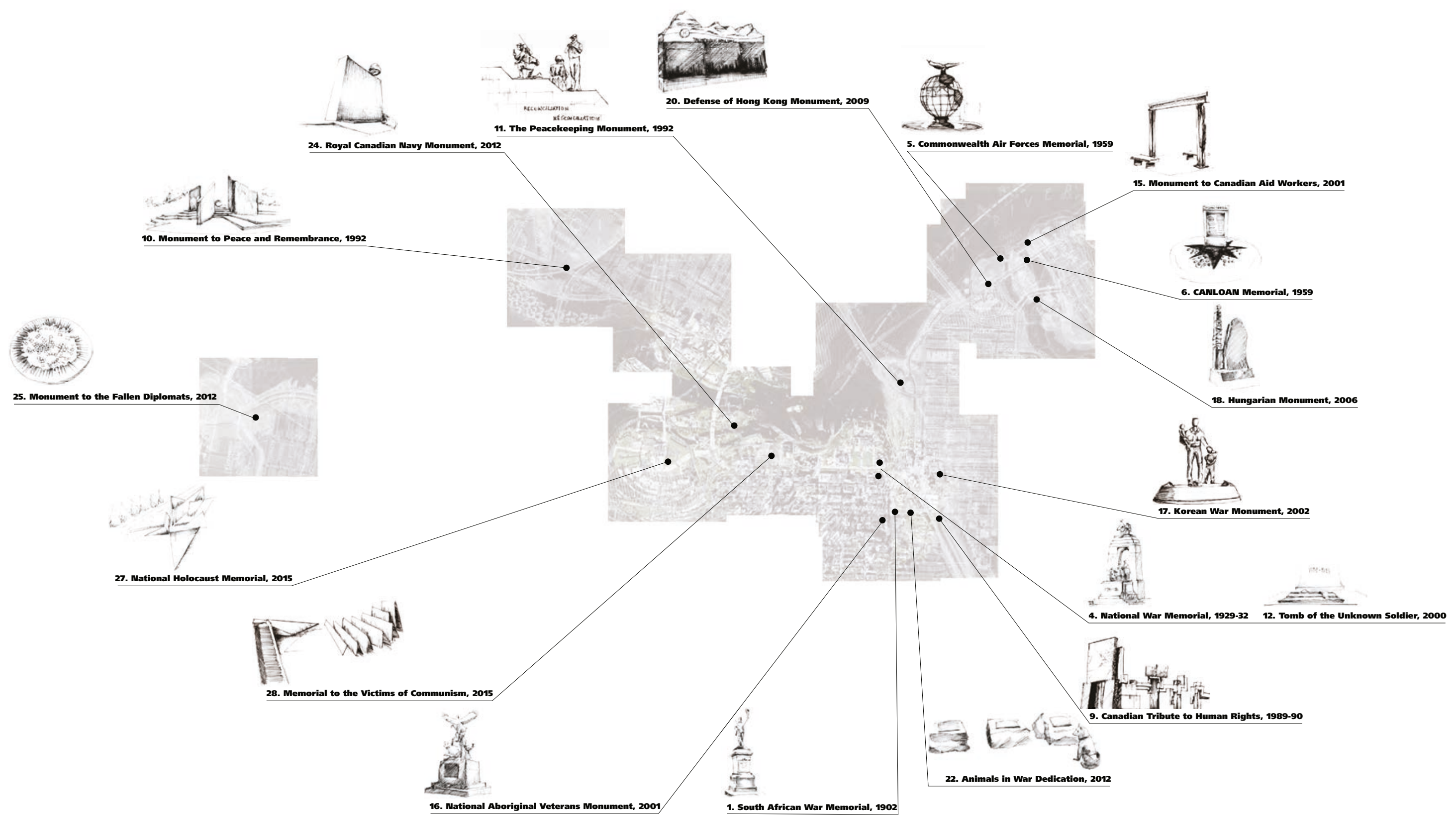




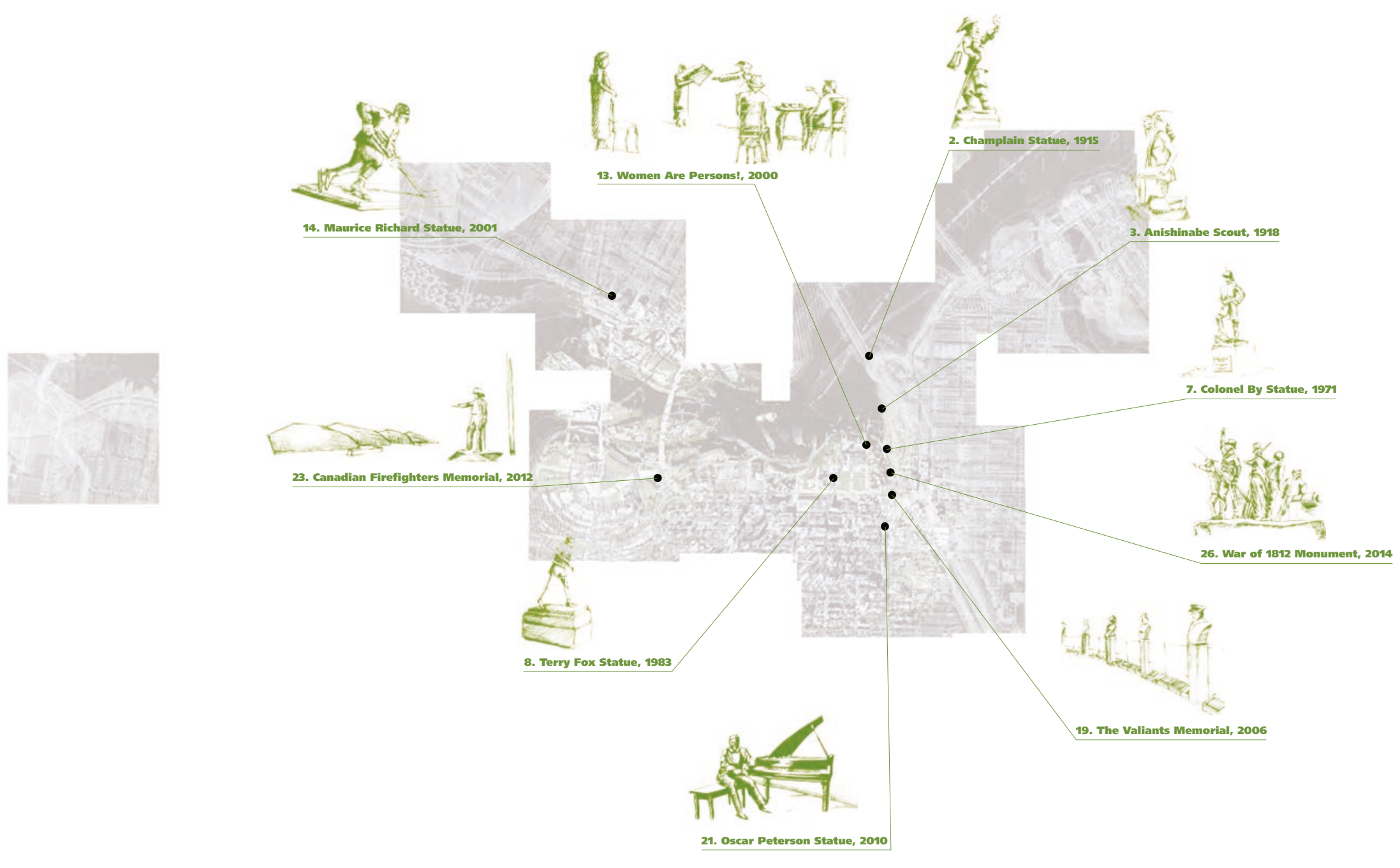



Absent History and Misplaced Memories

In brief, with the design of a civic memorial, need is to tone down the space and thematic distancing from the context and the communal practice of the city. While the project's site directly confronts the memories of the wars (war museum) and the Holocaust, this civic memorial should be put in conversation with both memorials to extract the communal character of the memorialized matter and people. Libeskind's team based its design concept on the classification system in Nazi concentration camps during WWII. The victims of persecution were split into six categories, represented by the six triangles shaping the Star of David. Rather than introducing the Star of David as a symbol of Judaism, the polish-born architect decomposed the memorial space into six entities, each representing a different view of the experienced persecution.

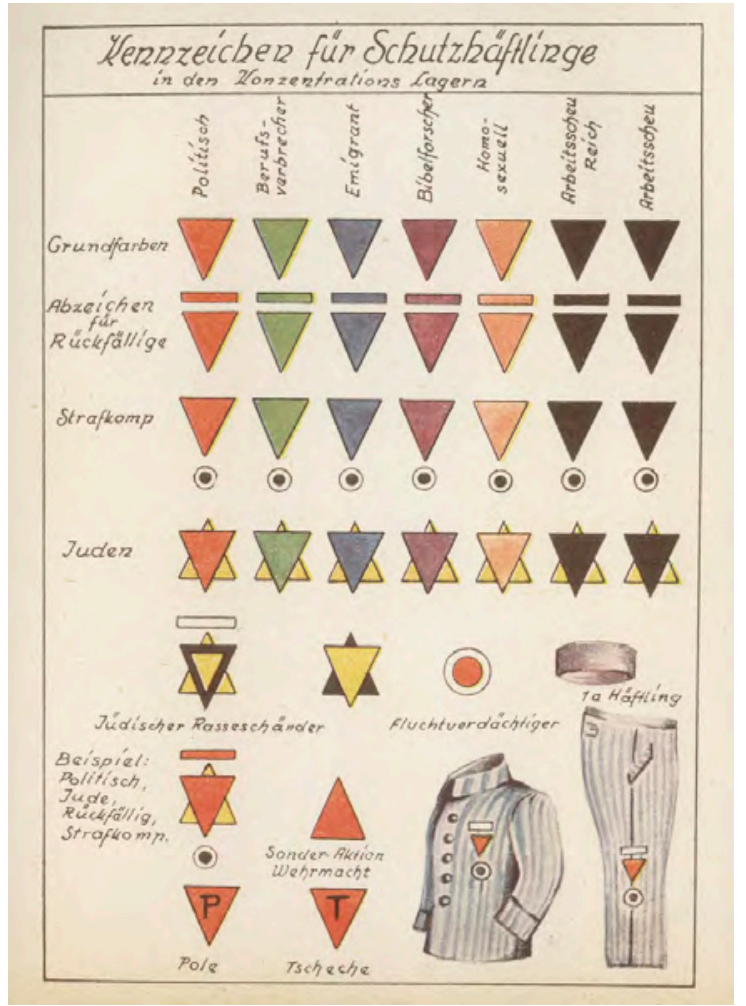

When looking at the main themes and sources of inspiration for this project, there are evidently no visible correlations to the site. However, the transition between the memory narrated by Libeskind's project and that narrated by the site expresses a dichotomous dialogue between racial seclusion of 1930s and 40s Germany and the gathering of immigrants that shaped the community of LeBreton Flats. While the memory of the Holocaust in itself cannot provide a clear understanding of the ottawan context, its opposition to a subtler local reality may highlight and ease the readability of the local in relation to the "other". If the space of the civic memorial integrates different approaches to a communal life drawn from distant contexts, the visitor is reminded of the particularities of living in Ottawa.

(19) Naziconcentration camps:racialclassification system for prisoners. 
37 IV. A Civic memorial on LeBreton Flats: Absent History and Misplaced Memories

The Portrait Gallery: an informative mosaic of past milieus and their people

The memorial now occupying a historical space and participating in the present practice, a certain amount of informative material has to ease the readability of the very reason for being of this architectural intervention: What are we remembering? The civic memorial aims to commemorate that through the diversity of lifestyles, of personal backgrounds and of uses of the site, LeBreton Flats and the people and activities they house, have remained an essential influence in the shaping of Ottawa. Since the theme of the recollection is not as specific as that of Holocaust or other War memorials, lifestyle photographs and informal portraits seem to be the perfect medium to express social diversity and changes. At the same time, portraits and vernacular photography act as reflections and projections of the visitors' body and surroundings in the context of the photograph. While crossing the site, one witnesses simultaneously (physically and visually) its current conditions and how it used to be.

Over the years, Library and Archives Canada has collected a large collection of portraits of Canadians "by Canadian and international artists as well as images by ordinary people $(. .$.$) - with the goal of documenting historical personalities important$ to Canada's development" (LAC: Portrait Portal)

The people illustrated in that collection - the workers, businessmen, residents - constitute the core memories of this project. Celebrating them, their diversity and their actions means a recognition and engagement with changes and transitions in the city and within the society.

At the moment, the Canadian National Portrait Gallery remains a purely digital project. With no current space to exhibit it, the collection is stored away in the Archives buildings in downtown Ottawa and in Gatineau. The design of the memorial would therefore allow a part of those works to be introduced to the public in a proper Ottawan context.

It is important to note that designing an intangible experience tends to rely more on aesthetics, movements and transitions in the space than on a particular architecture program. The portrait exhibition space is not necessarily the central motivation to the design of a memorial. The portrait collection is suggested as an aid, a scenographic apparatus, to heighten the involvement between the visitor and the memorialized material and people. 
(20) The Flats: a mosaic of moments in time and space

(21) Britannia Terrace: A historical solution to current circulation issues
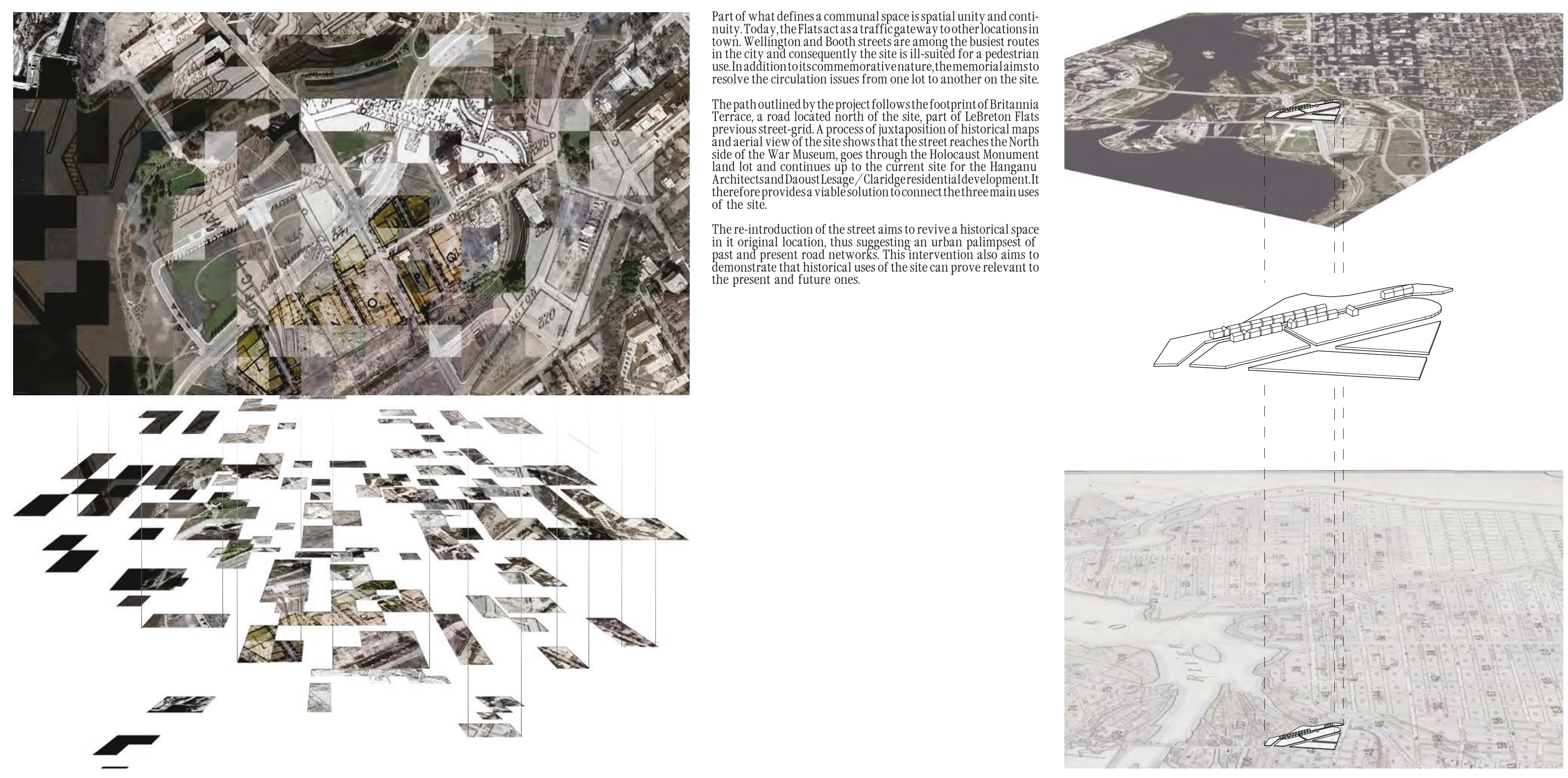
This project is a landscape
intervention on LeBreton Flats aiming to change the presen
and future site dynamics. In light of the current use of
the site, the ground North of the site, the ground North of
the Flats has been lifted to freeasubterranean needestrian
path to connect the lots of the path to connect the lots of the
War Museum, the National Holocaust Monument and the
residential development.

The building is accessed by
two staircases equipped with bicyclerailsand anelevatorlocated North of the War Muse-
um and East of the completed um and East of the completed
condominium building. Their
location allows a coninumalocation allows a continina-
tion of the visitor's trajectory
tots fion of the memorial onto the
frodestrian and cyclists track
ped pedestrian and cyclistst trat
on the site. Both accesses to ground tunnel - located 6 meters under the ground level
crossingBoothand Wellingto streetsand reachinginthecentr
lot, where the Holocaust Mon ument and the civic memorial

Once the central lot is reached, ly opens up to the site. The
spatial dilatation in plan an

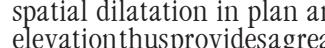
er contact with the site and an
interios $s$ nce more sited to

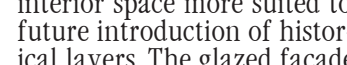
ical layers. The glazed facaa
providesa visual contact, from the memorial space with al
three memories functions three memories functions
the site. Meanwhile, the roo
oblique plane inter oblique plane intersects and
merges with the ground sur face to allow visitors to dwell
on the site and keep enjoying
its snique location and views.

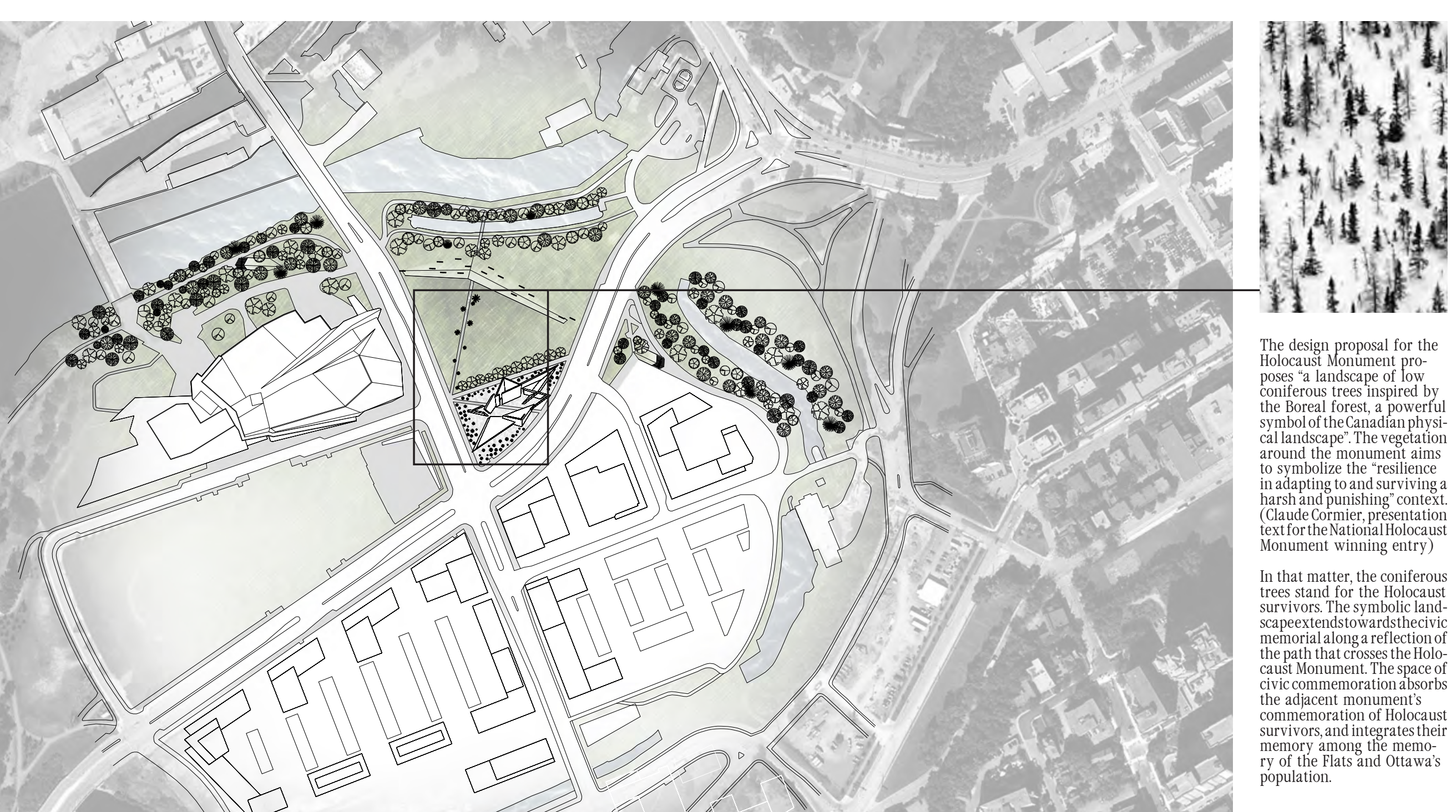



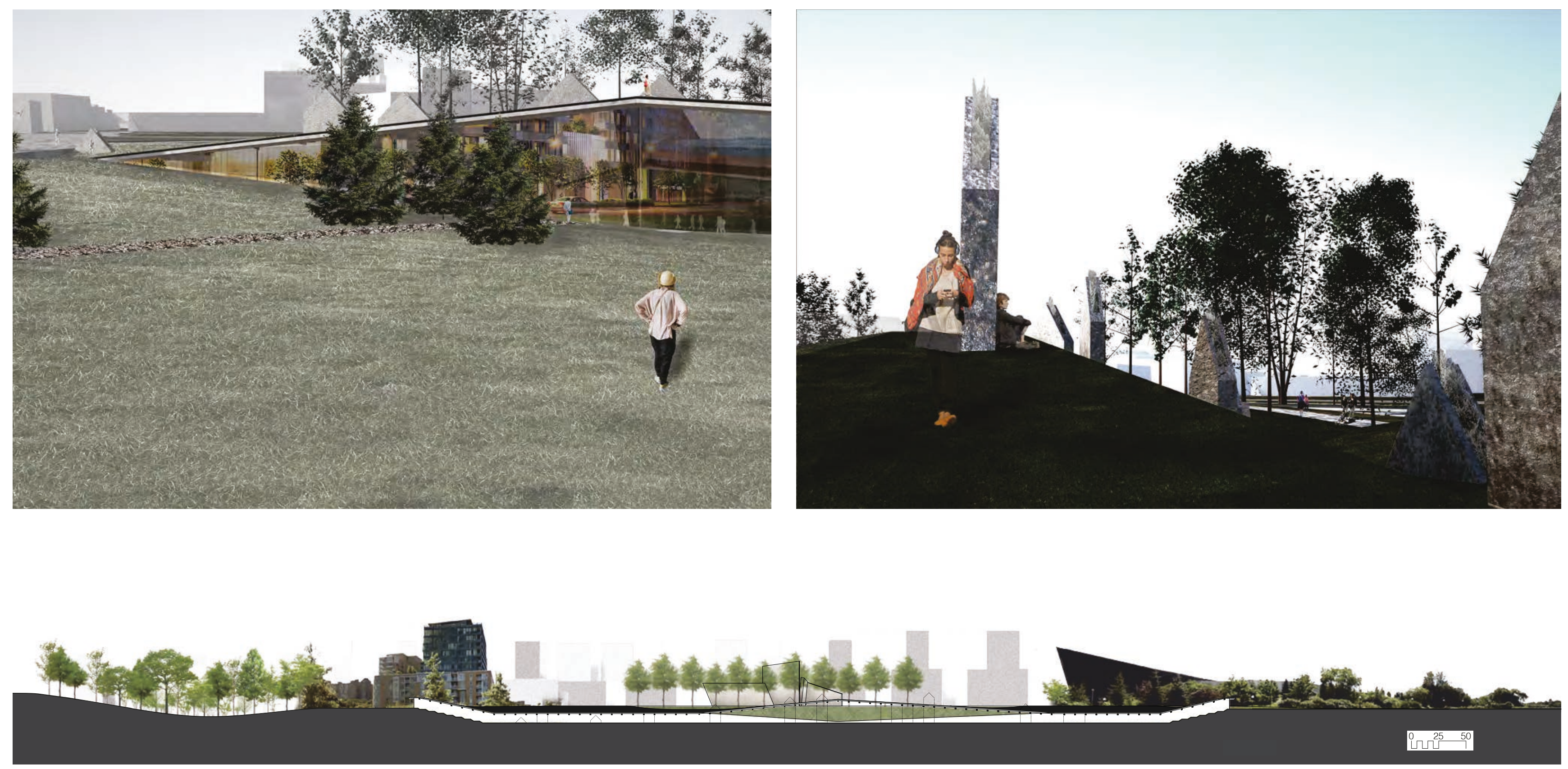
41 IV. A Civic memorial on LeBreton Flats: Absent History and Misplaced Memories
(26) Crossing the Memorial: a toggle between past and present (Cross-sections) 
42 IV. A Civic memorial on LeBreton Flats:

Absent History and Misplaced Memories

(27) House-facade shaped walls: signiflers of an absent reality

(28) Floor plan
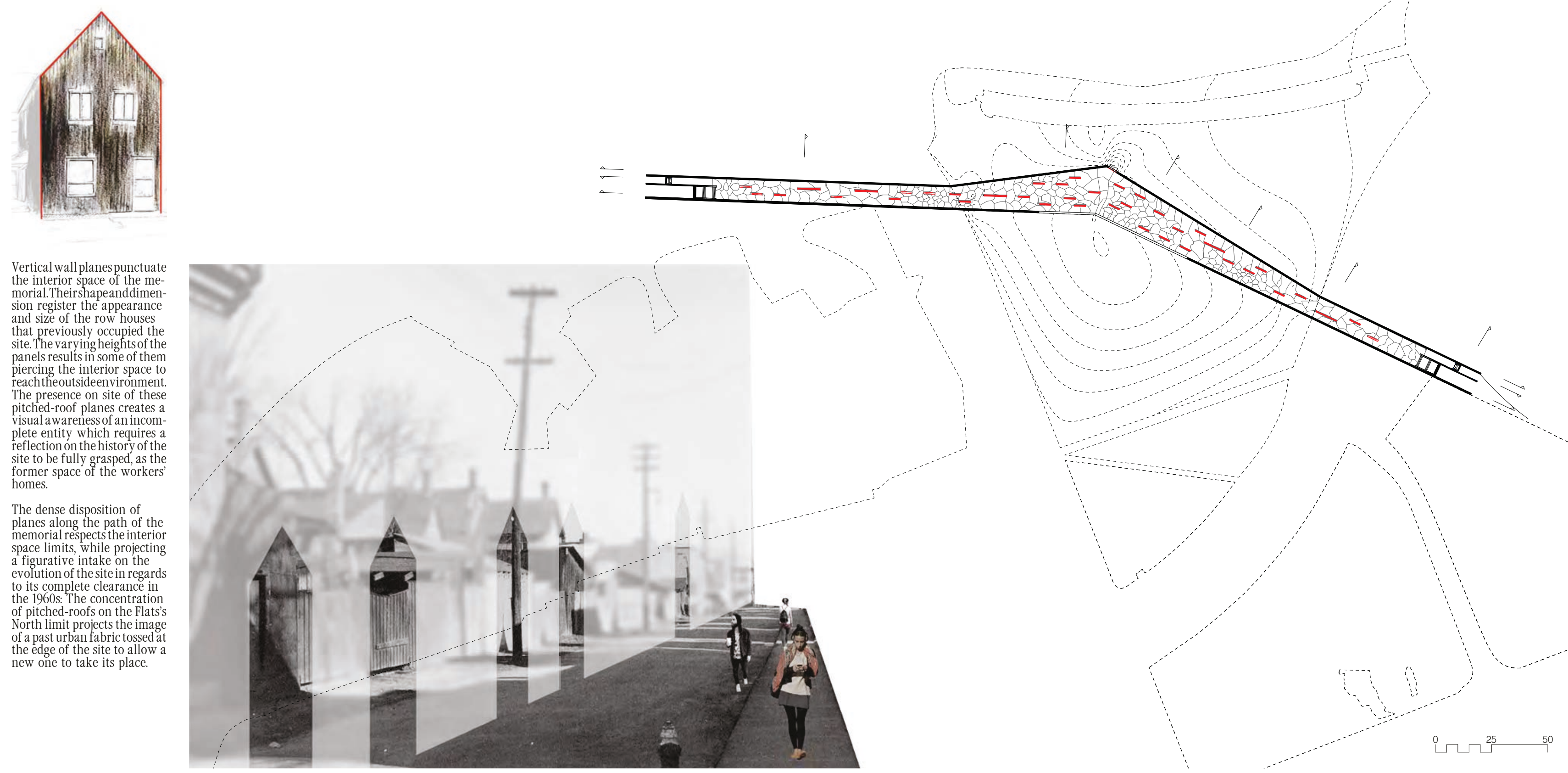

Vertical wall planespunctuate
the interior space of the me-

sion register the appearance

and size of the row houses

that previously occupied the
site.-The varyiningheightsof the

panels results in some of the
piercing the interior space

The presencece on site of these

sual awareness of an incon-

lete entity which requires a
eflection on the history of the

site to be sully grasped, as kher
former space of the worker

The dense disposition of
planes along the path of the memorial respectst the interior
space limits, while proiecting a ligurative intake on the

its complete

of pitched-roofs on the Flats

North limit proiects the ima

the edge of the site to allow 


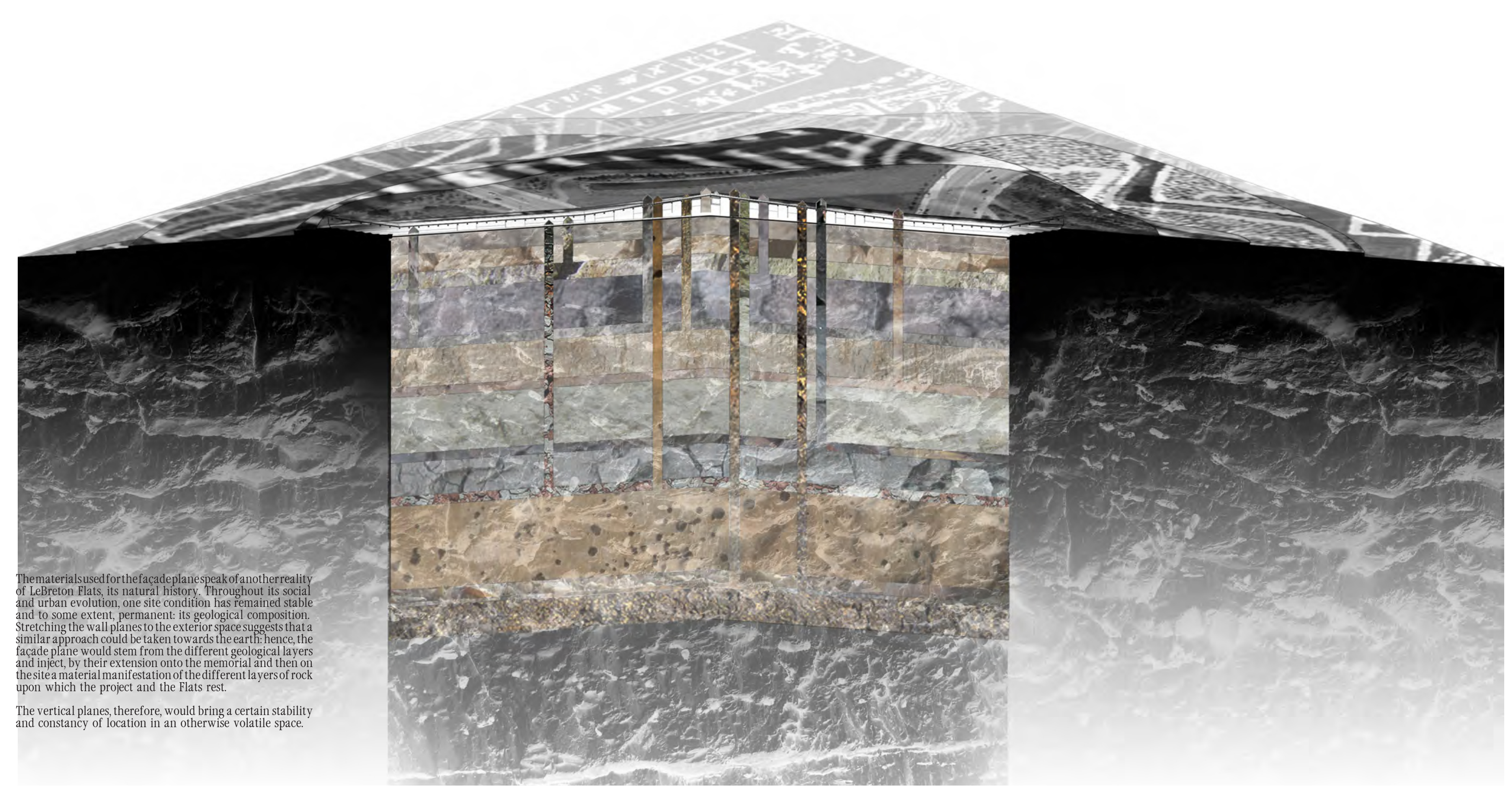


IV. A Civic memorial on LeBreton Flats:

Absent History and Misplaced Memories

\section{(30) Portaging through time: the site $s$ past uses expressed in the materiality of the project}

\begin{abstract}
By following the proposed layout, the project allows to move through the land in a way and for similar motives that invited past travellers to portage through the flats. This practice - the carriage of the canoe, and the crossing of the site along the river - engaged the traveller's body and mind with thesite'snaturalqualities, potentials, and dangers. While portage trails usually began as natural tracks, and were later improved by tramping or blazing, the idea and need of an unobstructed path remains the same as it is today with the traffic flow.
\end{abstract}

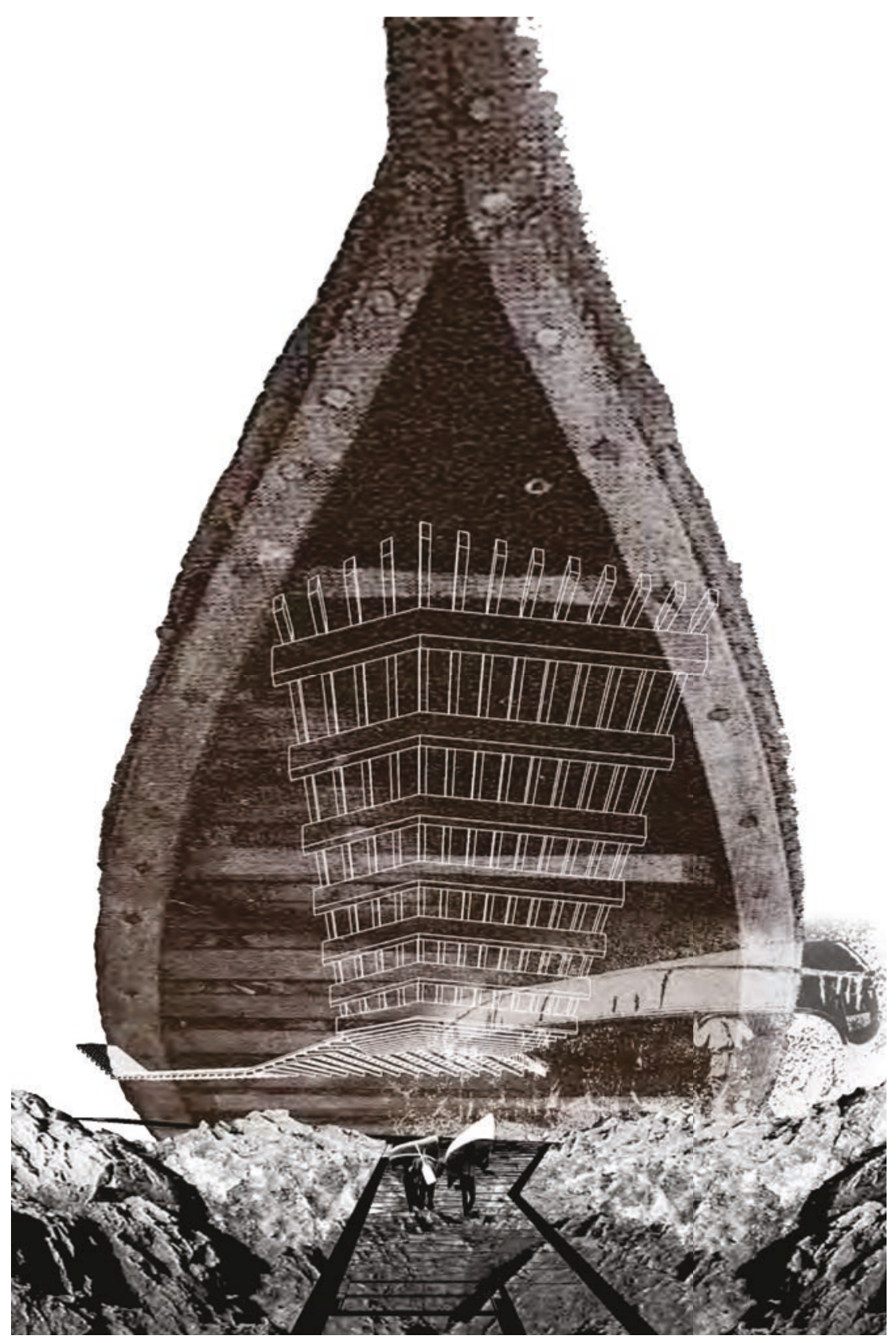


45 IV. A Civic memorial on LeBreton Flats:

Absent History and Misplaced Memories

(31) Geological palimpsest: encounter with the site's natural past Interior view 
46 IV. A Civic memorial on LeBreton Flats:

Absent History and Misplaced Memories

Othernaturalinfluencess,suchastheever-changing climatepromoteadeeperrelationshipbetweenthe
meteoroloogical condititions and the memorialization. The dense foggy morningsweexperienceduring the fall season would create that veil reminiscent of
the smoke that covered the flats during the Great Fire of 1900 .
(32) The natural Climatic conditions: actors in the experience of memorialization

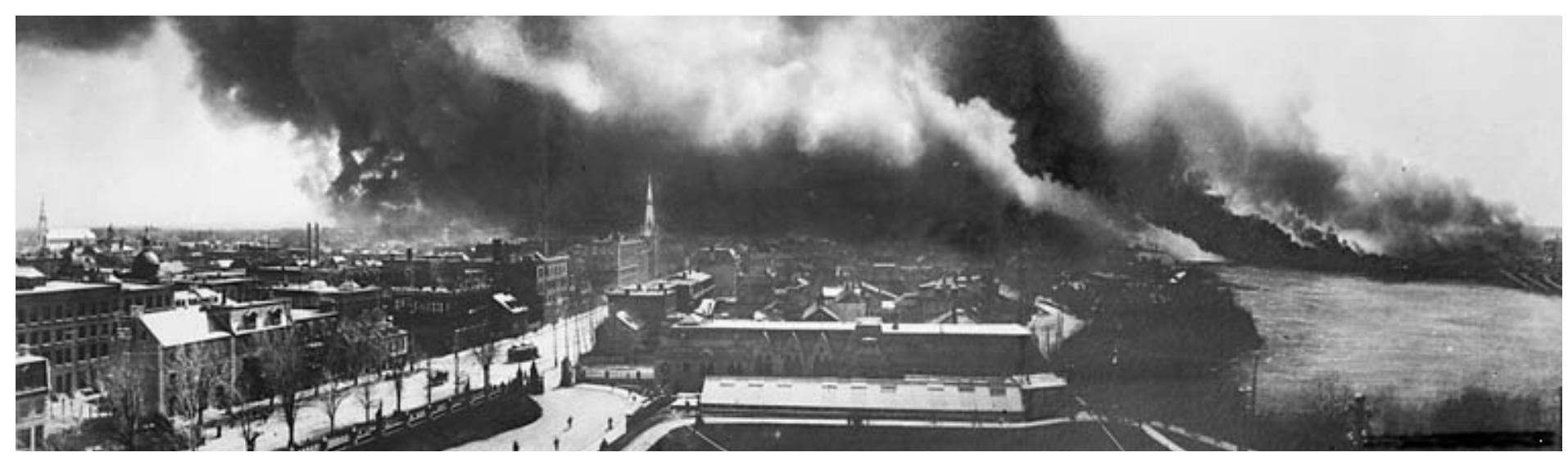




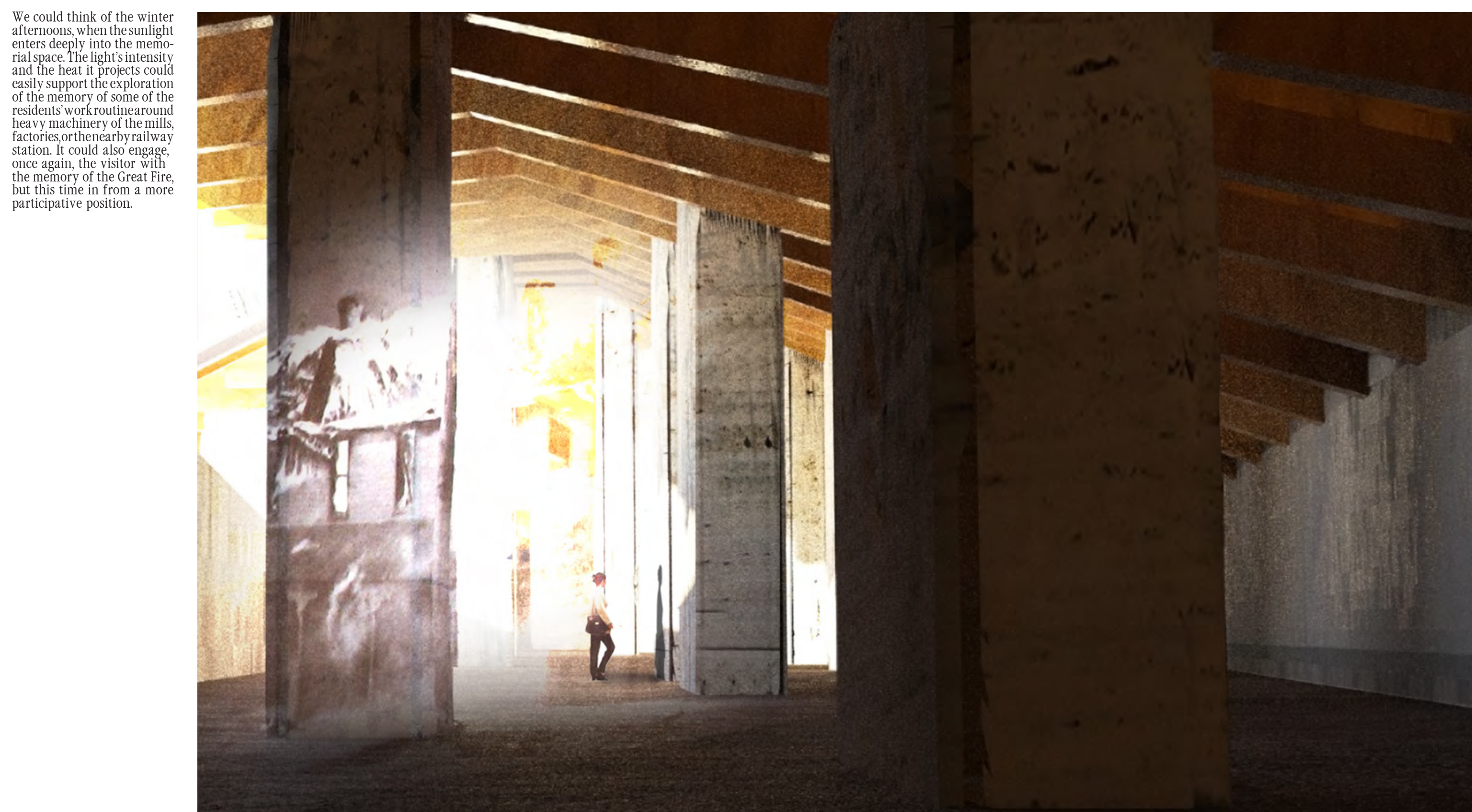



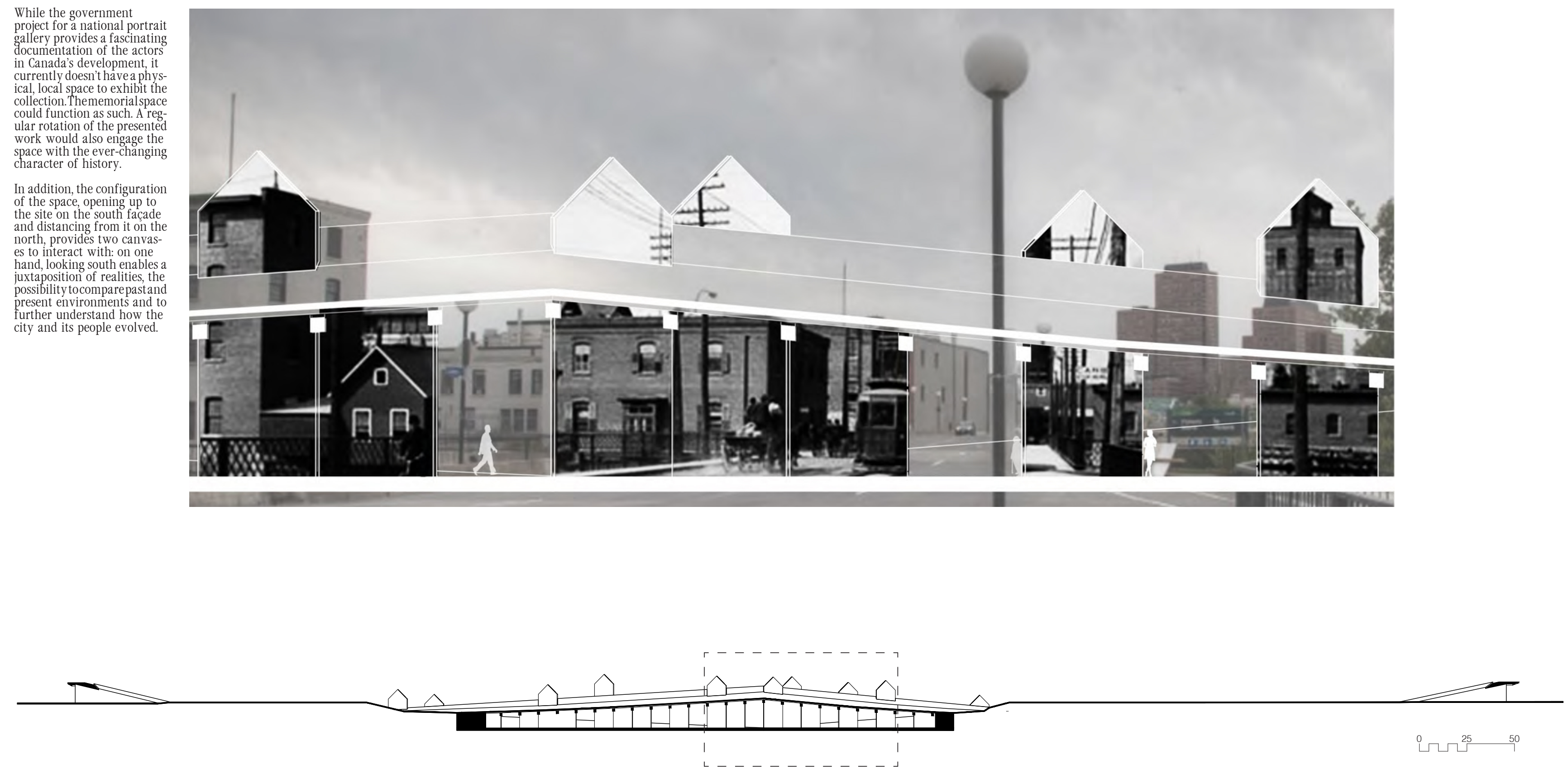

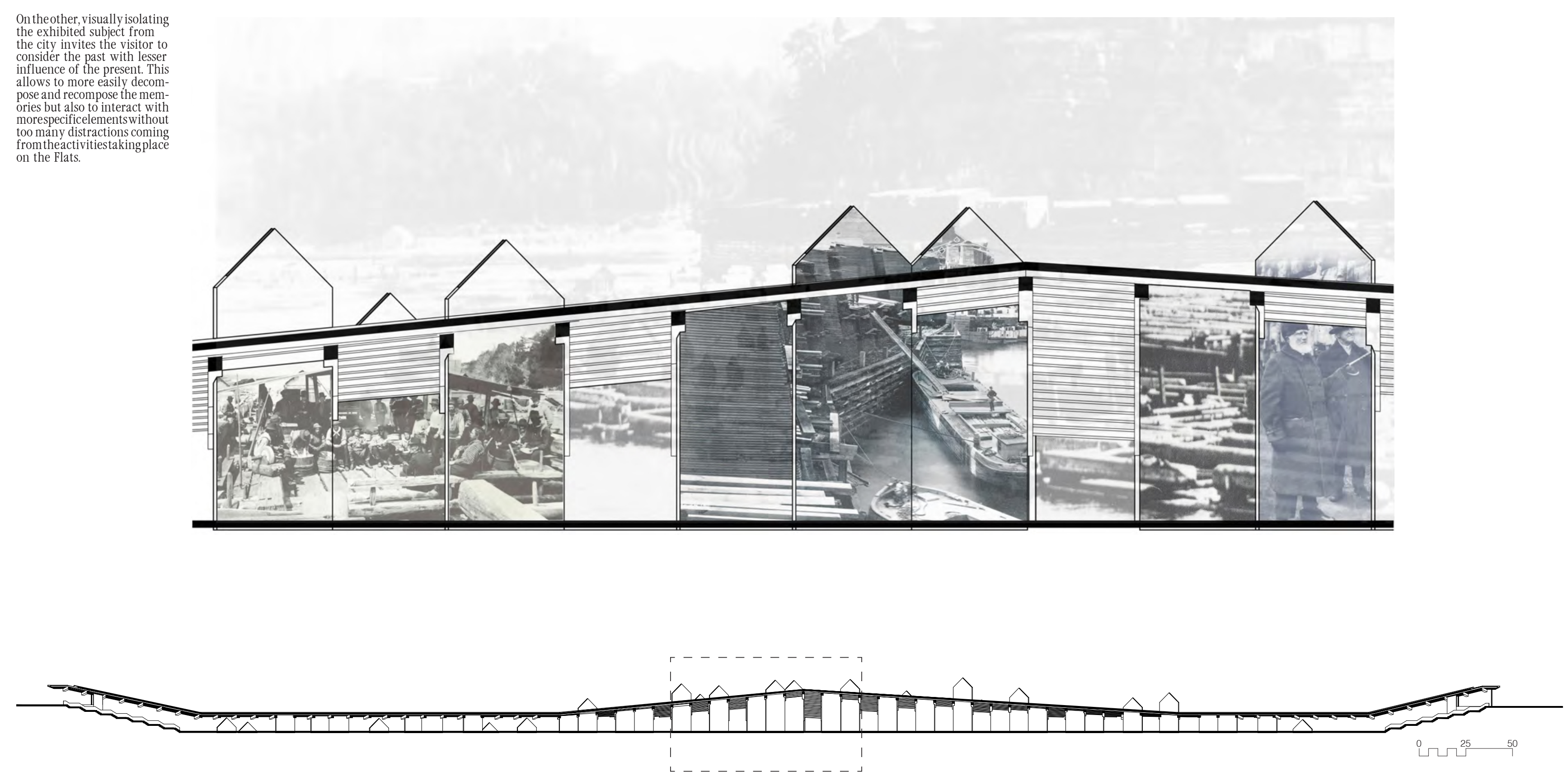
Introducinglargesizeprintsandoriginal photographsandportrait
from thelibrary and ArchivesCanada collectionallowsthereconstruction of an
past and presen

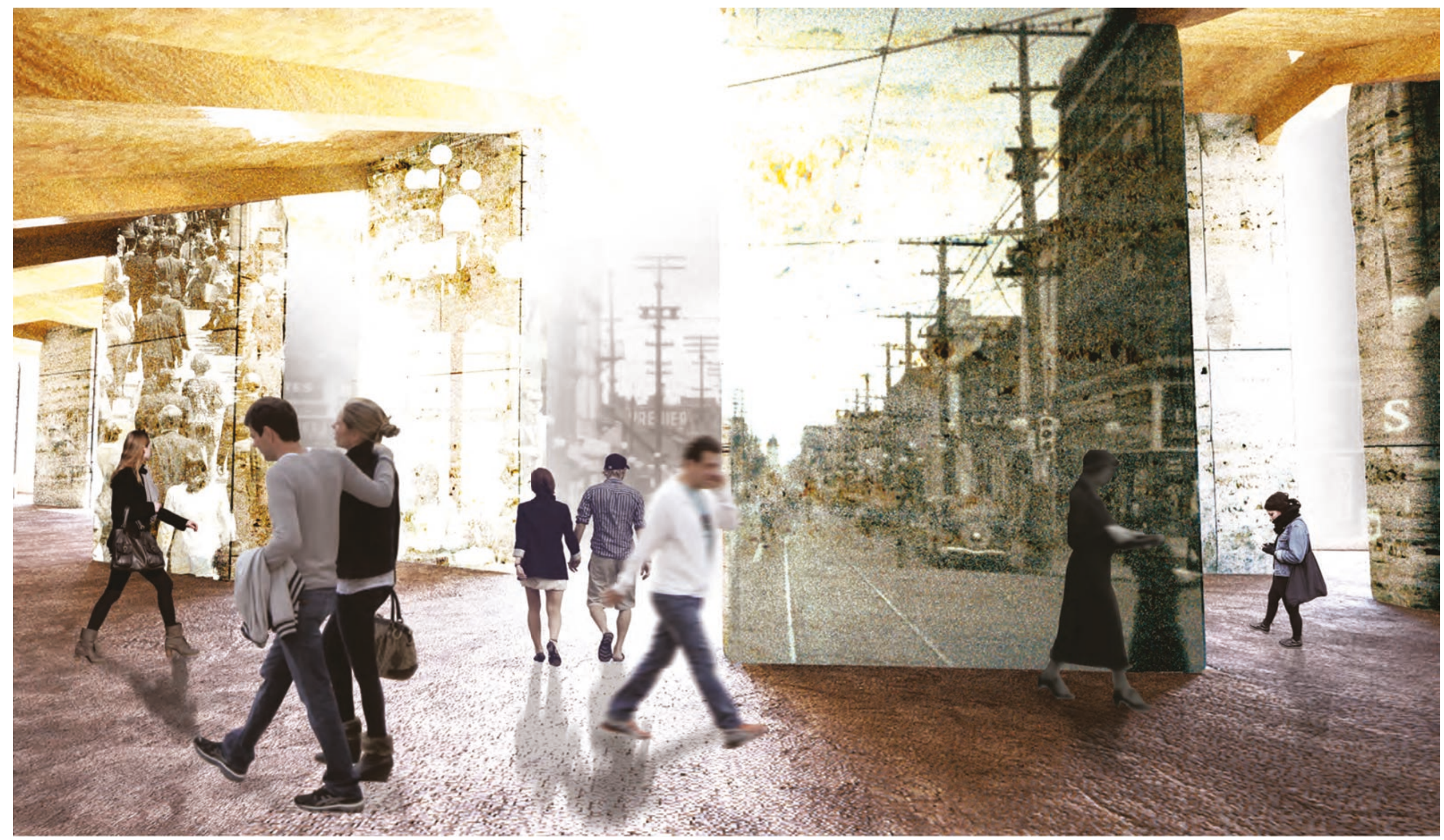



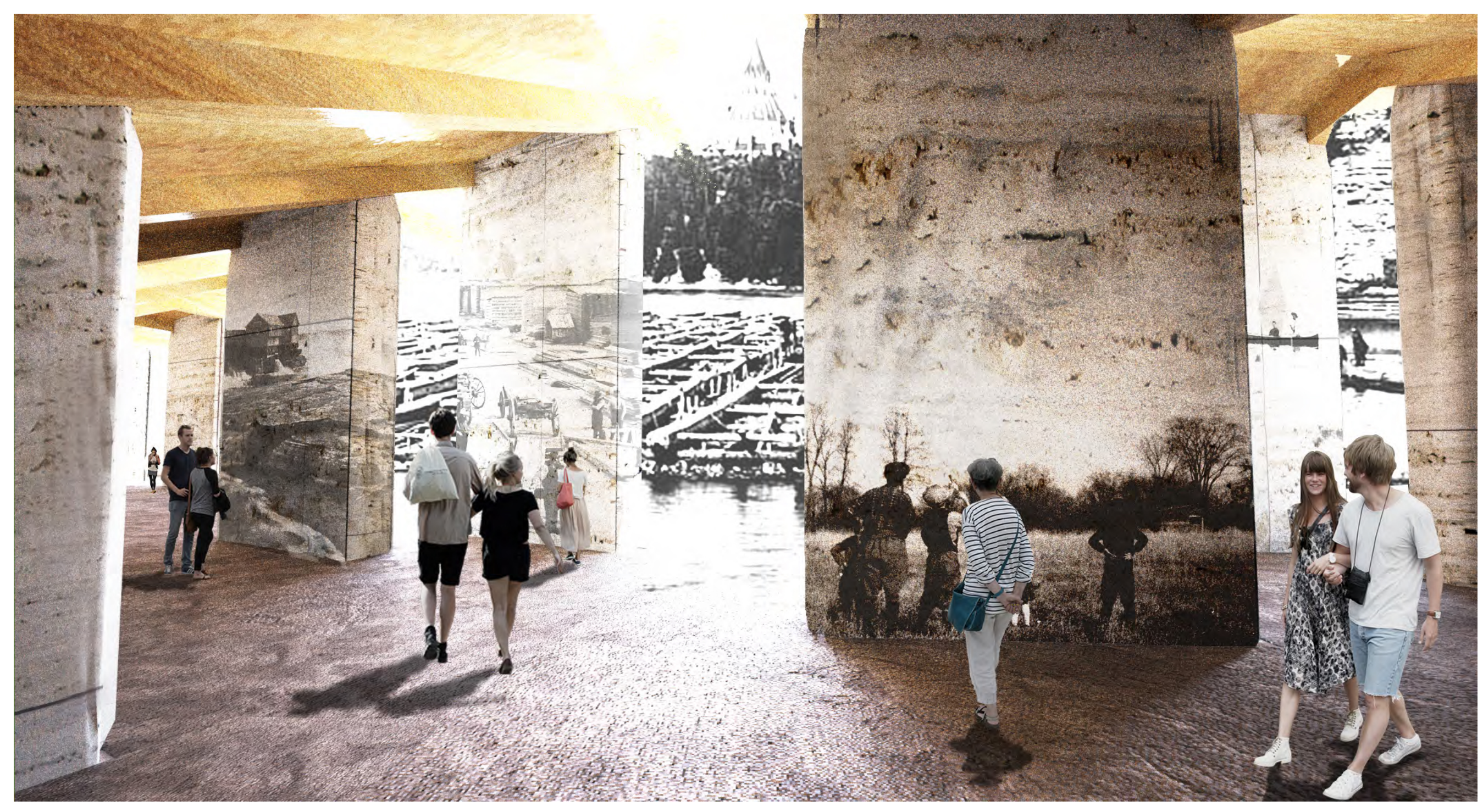


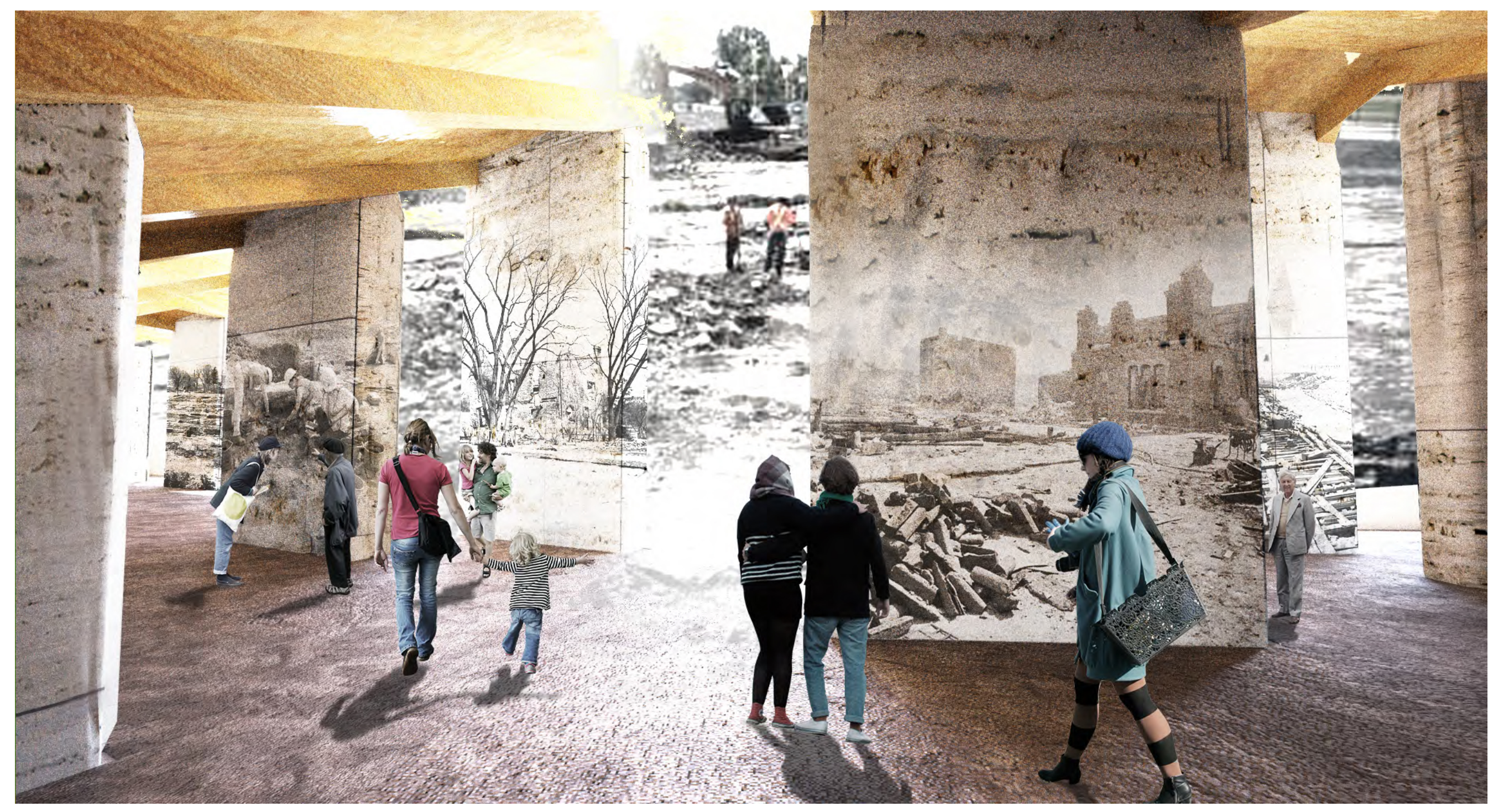




\section{Endotes}

4. "The acre was part of one family's territory, operating under unwritten guidelines. The guidelines were tools, whittled from experience, designed to ensure long-term survival.

To show how these guidelines worked, let's reverse the flow of history. Imagine Champlain is not here to impose Frenchness. Instead, he is here as a guest, in another's home. Anxious not to offend, and looking to settle in the area, he wants to learn the ropes as quickly as possible. What, he asks his companion in the canoe, do I need to know to make a go of it? In his journal that night, Champlain writes down what he can remember.

- The border of a family's territory, nokiwaki, isn't marked out with fences or stone walls; it is understood. A river, a ridge, a lakeshore, a swamp, a clump of cedar or pine may mark the perimeter of understanding. A territory is defined by the ability to sustain the family, its yield, not by its acreage. If disease, fire, or natural cycle reduces the yield, the understanding will grow accordingly.

- The seasons have shown that, on average, one hunter can provide for three non-hunters.

- The family with a large territory stands in no more regard than the family with less. Bigger than, and smaller than, bear no relation to status or wealth.

- One hunter can manage only so much trapline. To extend a trapline beyond what a hunter can harvest makes no sense.

- The islands are common territory. Hunting on islands is a communal affair, done by driving the animals from the center to the edges, where hunters wait in canoes.

- The territory around the summer camp is reserved for older hunters, whose horizons are closer than those of younger men

- There are times of abundance and times of scarcity, and no one escapes them. A family experiencing scarcity turns to a family in the abundance and asks for territory to be shared.

- Someone from another territory, passing through, may be hungry and make a kill. So be it. The resulting pelt is given or delivered to the host family. The open invitation by the visiting hunter to make a reciprocal kill on his territory is understood.

- On a good day, a moose or caribou will be taken. The antlers are placed on a trimmed tree stump, the skull in the branches of a nearby tree. Forget to do this, or show lack of respect, and the next kill will be harder, or fail. On a very good day, a bear will die. Paint the skull with two stripes at right angles, making four quadrants. Put a dot in each quadrant. Trim the bark from a spruce tree, hoop the trunk with red painted stripes, and tie the skull to the tree. Attach ribbons to the treetop.

- Sometimes hunters kill without respect. To kill a beaver in another family's territory and then try to keep it secret is the greatest disrespect. The wronged family will undoubtedly ask the shaman to make the hunter suffer illness.

- Eating a slice of the kill at the moment its spirit leaves, but not before, will ensure further kills.

- The discovery of a new beaver lodge is celebrated by putting a blaze on a nearby tree.

- No more than two-thirds of the adult beavers in a lodge should be taken form one spring to the next.

- The family territory should have a nucleus that is left unhunted, in case of emergency. The remainder should be divided in four, and each quarter hunted in turn.

- There are some gifts of the forest that never know scarcity, such as berries and birch bark. These are for common harvest, by anyone who needs them.

- A white animal coming into the territory is bad luck.

There is, naturally, no way Champlain could abandon centuries of hardened attitude, and see the acre -- all the acres -- from the other man's point of view, any more than the woodlander can see the river and hills from Champlain's. They cannot change places in the canoe." (Jenkins, 1996: 55-57)

5. Robert Randall was an American merchant. Caught trying to bribe American congressmen, he saw in moving to Canada an opportunity to start again his life with a clean slate. He first settled near the Niagara Falls. With no success in business there, he would juggle locations and properties for twelve years before purchasing a lot of land on the Flats in 1807. In the following years, Randall managed to become the owner of several businesses, along with having the lease on 3,400 acres of land in Canada. His new success in business didn't stop his past failures to eventually resurface. In the spring of 1809 , creditors from Niagara caught up to him and had him "locked up in debtors' prison." (Jenkins, 1996: 104-5) At that time, Randall lost his lands and when he passed in 1834, he did so as a "Victim of Colonial Misrule" (ibid.: 123) 


\section{Postscript}

In order to survive, local identities and memories depend on contemporary society to transmit and communicate its narratives to future generations. However, in order for a society to be strong, just and long lasting it must adopt a structure based on the concepts of law, order and a civil community. A civic population is usually reminded of these essential themes by a set of institutions both actual and symbolic including the Parliamentary District and its buildings, the Supreme Court, National Institutions, memorials and Museums as well as the influencial urban spaces which they occupy. Within or adjacent to these sites lie historically significant urban neighborhoods, such as LeBreton Flats - the site of this Thesis study and project.

Recent decisions by the Government of Canada and the National Capital Commission will introduce in this context a memorial and a monument with the expressed purpose to raise public awareness of two historical themes: The traumatic human tragedy of the Holocaust and the oppression of people by communist regimes throughout the world. One would not argue the importance of such events and the need for their commemoration. However, to do so by compromising the significance and visibility of adjacent historical sites and buildings in the process shows a lack of responsibility towards our local and national heritage and identity. With the forthcoming construction and inauguration of the National Holocaust Monument on LeBreton Flats and the future construction of the Tribute to Liberty Memorial to be sited on the eastern wing of the Supreme Court building plaza, one needs to question the approach as well as the adequacy of how collective memory is expressed and translated in the space of the city. For all intents and purposes, these proposed commemorations will reflect on their respective narratives while standing apart from their physical/historical contexts and associated collective storylines.

Commemorative apparatuses have been developed around the idea that exceptionally important events or actors of the past need to be remembered and taken into consideration in our present and future actions as individuals, as well as members of a society. This thesis supports the idea that part of that responsibility to remember is accounted in the preservation of the historical singularities that distinguish a city such as the Canadian Capital from other urban 
spaces. Societies, including ours, have reached a state where knowledge and information are readily available with such density and ease of access that it is easy to forget that there may be other pertinent information to seek and a deeper context to explore. The building of "official" memorials and monuments, in my opinion, represents the epitome of this phenomenon - a form of contextual nearsightedness. By prioritizing the memories expressed by these constructions over any other context our country's officials are, in effect, prescribing remembering. What does this say for the other narratives that are not embodied in such structures but that exist nonetheless in the surrounding physical grounds of the city?

While the extermination of Jews, Slavs and other European minorities is being monumentalized by the National Holocaust Monument on LeBreton Flats, the site's past community, whose participation to the development of Ottawa was crucial, is being forgotten. Meanwhile, with the erection of the Tribute to Liberty Memorial meant to revive the memory of oppressive regimes that touched many parts of the world, the image of Canada's legal and judicial system emblematized by the Supreme Court building and its symmetrical grounds looses clarity. Whether we want it or not, commemorative apparatuses permanently add a new layer of content over the urban space that they inhabit, and in choosing to build them, we take on the responsibility of forever changing the meaning of that space for future generations.

This Thesis' proposal for a civic de-monumentalized memorial was designed as a transitional space rather than as a static environment, intent on immersing visitors in a narrative that distances them from the immediate pressures of the city. Treating the memorializing experience as a flexible or re-definable pilgrimage means that local visitors are able to seek their own paths and hence their own "roots", while remaining intertwined with the current and future uses of the site. Thus, the project aims to materialize the fact that memories from the past do not have a fixed narrative; in fact, personal and shared memories are fleeting and often influenced and tinted by elements from other contexts. As such, memories are ephemeral moments in the consciousness of individuals as well as communities. What is permanent in the act of recollection is its influence 


\section{Postscript}

on our perceptions and actions in the present time. Therefore by activating the pilgrimage of Canadians within their National Capital this project provides a functional and experiential connection between past and present by engaging and intersecting the numerous paths of this important site. In addition, with its ever-changing displays and contents, the project's architecture introduces the public to the dynamic past of the site and invites them to reflect on their environment and to reconsider its importance among other spaces of recollection in the city. Ottawa has a rich and fascinating history, one of Town and Crown, that deserves to be recognized and disseminated. This can only be achieved by searching deeper than what its monuments and memorials command us to remember. 


\section{Bibliography}

Alivizaton, M. (2012). Intangible Heritage and the Museum: New Perspectives on Cultural Preservation. Walnut Creek, CA: Left Coast Press.

Augé, M. (1992). Non-Lieux: Introduction à une Anthropologie de la Surmodernité. Paris: Éditions du Seuil.

Bachelard, G. (2001). La Poétique de l'Espace (8th ed.). Paris: Quadrige/PUF.

Barthes, R. (1991). Mythologies (A. Lavers, Trans.). New York: The Noonday Press.

Bastéa, E. (2004). Memory and Architecture. Albuquerque: University of New Mexico Press.

Baudrillard, J. (1994). Simulacra and Simulations. Ann Arbour: University of Michigan Press.

Bergson, H. (1990). Matter and Memory. New York: Zone Books.

Bornhöft, P. (2007, 11/05/2007). Commemoration Saturation: Can Berlin Handle Any More Memorials? Der Spiegel International. Retrieved from http://www.spiegel.de/international/germany/commemoration-saturation-can-berlin-handle-any-more-memorials-a-515733.html

Bourdieu, P. (1993). The Field of Cultural Production: Essays on Art and Literature (1st ed.). New York: Columbia University Press.

Casey, E. S. (1997). Smooth Spaces and Rough-Edged Places: The Hidden History of Place. The Review of Metaphysics, 51(2), 29.

Certeau, M. D. (1984). Walking in the City Practice of Everyday Life. Berkeley: University of California Press.
Debanné, J. (2005). Flats on the Flats. Canadian Architect, Vol. 50 No. 9 (September 2005), pp 42-5 Derrida, J. (1982). Positions. Chicago: University of Chicago Press.

Derrida, J. (1996). Archive Fever: A Freudian Impression. Chicago: University of Chicago Press.

Dollens, D. L. (1993). Sites: architecture. New York: Lumen.

Fenz Werner Kecht, M. R. (1989). The Monument is Invisible, the Sign is Visible. The MIT Press, 48(Spring 1989), 3.

Fine, C. (2008). The Britannica Guide to the Brain: A Guided Tour of the Brain - Mind, Memory, and Intelligence: Robinson.

Foucault, M. (Spring, 1986). Of Other Spaces. Diacritics, 16(1), 5.

Fraisse, P. (1957). Psychologie du temps : par Paul Fraisse. Paris; (VendÙme: Presses universitaires de France ; Impr. des Presses universitaires de France).

Frampton, K. (2002). Towards a Critical Regionalism: Six Points for an Architecture of Resistance The Anti-Aesthetic: Essays on Postmodern Culture (pp. 13). New York: New Press.

Freud, S. (1997). Writings on Art and Literature. Standford: Standford University Press.

Giguere, J. M. (2014). Characteristically American: memorial architecture, national identity, and the Egyptian revival. Knoxville: The University of Tennessee Press. 


\section{Bibliography}

Goldberger, P. (1982). VIETNAM MEMORIAL: QUESTIONS OF ARCHITECTURE; An Appraisal. New York Times, p. C.25. Retrieved from http://carletonu.summon. serialssolutions.com/2.0.0/link/0/eLvHCXMwnV1NS8NAEB20XjxZ0eJXYf9ANB-bxNWDhJBgwVi1rdeyyW5ACGmM9v87kzRYSrx4DizLbnjzZufNGwDHvjaNHUy4xbu301TRswXPKMohrVWW5as8VzxtepVD-2VhzwLqXe9clTa33YFkg9xqldGj-Q11aHmm4_CH6tOgKVJUbd2M1NiHA4xjLkm8Qifut5Pq5spt428TVOIj6BRKrZTkV5FU41ISItrj2fjfrQ5hSHBWyUrXLGj_ImPYO-UJiPdJNH8OEpZEyfRtEjzdsddFNGvai9kOZIROQnwLSR9xz4KSIXGt5ceXLE5hHEfz8NHotrNURbEU3Ed-YGFaOoJBuSr1GbCMI-UyNRcZOb95tpSYtDoid5Xnptr3zmHUv8bFXx8u4dASSNupyO5fweC7XusxGVeOh7f-AYXDnOM

Halbwachs, M. (1980). The Collective Memory (1st ed.) New York / London: Harper and Row.

Heidegger, M. (1977). The Thing Basic Writings by Martin Heidegger. New York: Harper and Row.

Holl, S. J. P. A. P.-G. (2006). Questions of Perception: Phenomenology of Architecture. San Francisco: William Stout Publishers.

Hornstein, S. (2011). Losing Site: Architecture, Memory and Place. Surrey: Ashgate.

Huyssen, A. (2000). Present Pasts: Media Politics, Amnesia. Public Culture, 2(1), 17.

Huyssen, A. (2003). Present Pasts: Urban Palimpsests and the Politics of Memory. Standford: Standford University Press.

Jenkins, P. (1996). An Acre of Time. Toronto: Macfarlane Walter \& Row.

Jenks, C. (1969). Meaning in Architecture. New York: George Braziller.
Lefèvre, H. (1991). The Production of Space. Cambridge: Blackwell.

Libeskind, D. (1991). Countersign. London: Academy Publishers.

Libeskind, D. (2000). The Space of Encounter. New York: Universe Publishers.

Lyotard, J.-F. (1984). The Postmodern Condition (B. M. Goeff Bennington, Trans.). Minneapolis: University of Minneapolis Press.

Merleau-Ponty, M. (1962). Phenomenology of Percpetion. New York / London: Routledge.

Merleau-Ponty, M. (2005). The Visible and the Invisible. In T. Baldwin (Ed.), Basic Writings by Maurice Merleau-Ponty. New York / London: Routledge.

Minton, E. (1974). Ottawa: Reflections of the past. Toronto: Nelson, Foster and Scott LTD.

Morley, D. K. R. (1995). Spaces of Identity: Global Media, Electronic Landscapes and Cultural Boundaries. New York / London: Routledge.

Muschamp, H. (2002). The Memorial Would Live in the Architecture. New York Times, p. 2.1. Retrieved from http://carletonu.summon. serialssolutions.com/2.0.0/ link/0/eLvHCXMwnV1NS8NAEB20XjxZOeJHC_sHoptJOmVPEkKDBwVBpceyu92AUNIY7P93JulikXjxvLAsM8Ob_Xj7HkCCdzL6hQmJ1ZlzVF6oTap9hWit9BX1bysz090ULAt8ecfXnP-uB1WIfbYDSHblvd46vjS_T6kUmaApH5rPiF2k-LV1b6IxDCfUxzKmeBVJOSwnFXzIDvG3ayrIGQSGUk8I-WEktRRLPqUOaDb-d6ljGDOcNabxrcj7ajmHI19fAJMuxDMTbqkUxZItr8UTYaD4qAXtDkV-8NRwCbNy8VY8RmEBq_Vms0LF8i5Kx8kERvW29lcgKkqBjkOaO6woFVpbGRucKzl3SrIMXcNkel6bvwZu4TR4pCBOYfTV7vyMpSr6cO2-AVMCm_A 


\section{Bibliography}

Nietzsche, F. (2005). On the Use and Abuse of History for Life (I. C. Johnson, Trans.). New York: Cosimo.

Nora, P. (1997). Les Lieux de Mémoire. Paris: Quatro-Gallimard.

Pallasmaa, J. (2013). The Eyes of the Skin: Architecture of the Senses. Hoboken, NJ: John Wiler \& Sons.

Ruskin, J. (1907). The Seven Lamps of Architecture. London: George Allen \& Sons.

Samuel, R. (1994). Theaters of Memory (Vol. 1). London / New York: Verso.

Stamp, G. (2005). Too many memorials: Britain's ever-growing number of World War II memorials are marked more by vanity and kitsch than dignity and restraint -- unlike the monuments built after the Great War. Apollo, 161(520). https://proxy.library.carleton. ca/http://go.galegroup.com/ps/i.do?id=GALE\%-

7CA133605816\&v=2.1\&u=ocul_carleton\&it $=r \& p=A$ ONE\&sw=w\&asid $=347649$ ce7d29dcdf2d0fc96e9e994d27

Taylor, J. H. (1986). Ottawa: An Illustrated History. Toronto: James Lorimer \& Company.

Woods, S. E. (1980). Ottawa: The Capital of Canada. Toronto: Doubleday Canada Limited.

Yates, F. A. (1966). The Art of Memory. Chicago: The University of Chicago Press.

Young, J. E. (1989). 'After the Holocaust: National Attitudes to Jews' The Texture of Memory: Holocaust Memorials and Meaning. Holocaust Genocide Studies, 4(1), 13. doi: 10.1093/hgs/4.1.63
Young, J. E. (1992). Counter-Monument: Memory against Itself in Germany Today. Critical Inquiry, 18(2), 29.

Young, J. E. (1993). The Texture of Memory: Holocaust, Memorials and Meaning. New Haven / London: Yale University Press.

Young, J. E. (1993). Écrire le monument : site, mémoire, critique. Annales. Économies, Sociétés, Civilisations, 729743.

Young, J. E. (2000). Daniel Libeskind's Jewish Museum in Berlin: The Uncanny Arts of Memorial Architecture. Jewish Social Studies, 6(2), 1-23. doi: 10.2307/4467574

Zumthor, P. (1998). Thinking Architecture. Basel: Birkhäuser.

Library and Archives Canada. "Portrait Gallery of Canada". Portrait Portal. http://www.bac-lac.gc.ca/eng/ portrait-portal/Pages/portrait-portal.aspx. (retrieved 12.05.2014) 


\section{Illustrations Sources}

All aerial photographs and historical maps of the City of Ottawa were retrieved from:

MacOdrum Library GIS database (aerial views) at Carleton University (Ottawa, Ontario)

and

Library and Archives Canada. Collections Canada official website. Fire Insurance Plan - Ottawa.

$<$ http://www.collectionscanada.gc.ca/lac-bac/ results/arch?FormName=MIKAN+Simple+-

Search\&PageNum $=1 \&$ SortSpec $=$ score + desc \&Language $=$ eng\&QueryParser $=$ lac_mikan $\&$ Sources $=$ mikan\&Archives=\&Searchln_1=\&SearchlnText_1=\%22fire+insurance+plan\%22+ottawa\&Operator_1=AND\&Searchln_2=\&SearchlnText_2=\&Operator_2=AND\&Searchln_3=\&SearchInText_3=\&Media $=\&$ Level=\&MaterialDateOperator $=$ after $\&$ MaterialDate $=\&$ Digitallmages $=\&$ Source $=\&$ cain Ind=\&ResultCount $=10>$

(1) photo: James E. Young (2) photo: Jochen Gerz and Esther Shalev-Gerz

Source: Young, J. E. (1992) Counter-Monument: Memory against Itself in Germany Today. Critical Inquiry, 18(2), 275-277.

(3)(4)(5) photo: Tzvetelina Videnova

(6) photo: Berlin Partner GmbH

source: Crawford, B. (2009) Off the Wall | Berlin bash, in New York. TMagazine, blog for the New York Times, published online on March 30 2009, 1:11pm.

http://tmagazine.blogs.nytimes.com/2009/03/30/off-thewall-berlin-bash-in-new-york/?_r=0

(7) photo: Hu Totya

Source: Sacred Sites - International Foundation. Vietnam Veterans Memorial.

$<$ http://www.sacred-sites.org/saved-sacred-sites/vietnam-veterans-memorial/>
(12) Toronto Star. June,2 1966.

Source: NCC Watch. NCC Biggest Blunders: LeBreton Flats. http://nccwatch.org/blunders/lebreton.htm

(15) Map: Collections Canada (Library Archives Canada) source: Jenkins, P. (1996). An Acre of Time. Toronto: Macfarlane Walter \& Row.

$(8,14,16-18,20-31,33-38)$ by author

(9-11, 32) Collections Canada. (Library and Archives Canada)

<http://www.collectionscanada.gc.ca/lac-bac/results/ images?form=images_simple\&lang=eng\&startRecord $=1$ \&sortBy=score + desc \& digitalContentInd $=1$ \&query=ottawa\&mediaType $=>$ 